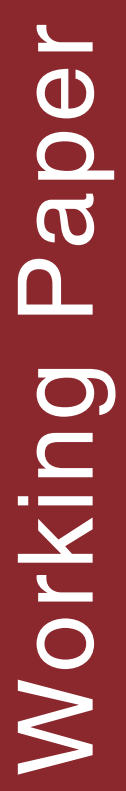

Endri Martini, Enggar Paramita, James M. Roshetko 

Agroforestry and Forestry in Sulawesi series:

\section{Information channels for disseminating innovative agroforestry practices to villages in Southern Sulawesi, Indonesia}

Endri Martini, Enggar Paramita, James M. Roshetko 


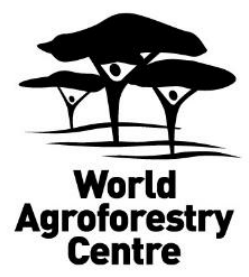

Citation: Martini E, Paramita E, Roshetko JM. 2016. Agroforestry and Forestry in Sulawesi series: Information channels for disseminating innovative agroforestry practices to villages in Southern Sulawesi, Indonesia. Working Paper 224. Bogor, Indonesia: World Agroforestry Centre (ICRAF) Southeast Asia Regional Program. DOI:

http://dx.doi.org/10.5716/WP16034.PDF

Titles in the Working Paper Series aim to disseminate interim results on agroforestry research and practices and stimulate feedback from the scientific community. Other publication series from the World Agroforestry Centre include: agroforestry perspectives, technical manuals and occasional papers.

Published by the World Agroforestry Centre (ICRAF)

Southeast Asia Regional Program

PO Box 161, Bogor 16001

Indonesia

Tel: +622518625415

Fax: +62 2518625416

Email: icraf-indonesia@cgiar.org

Website: http://www.worldagroforestry.org/regions/southeast_asia

(C) World Agroforestry Centre 2016

Working Paper no. 224

\section{Disclaimer and copyright}

The views expressed in this publication are those of the author(s) and not necessarily those of the World Agroforestry Centre. Articles appearing in this publication may be quoted or reproduced without charge, provided the source is acknowledged. All images remain the sole property of their source and may not be used for any purpose without written permission of the source. 


\section{About the authors}

Endri Martini has been working at the World Agroforestry Centre (ICRAF) as an agroforestry extension specialist with the Agroforestry and Forestry in Sulawesi (AgFor) project since 2011. Previously, she worked at ICRAF on various issues of agroforestry related to biodiversity conservation and community development. She obtained her master of science degree in natural resources and environmental management from the University of Hawaii at Manoa, USA. Her bachelor degree was from Institute Pertanian Bogor, Forestry Faculty, majoring in Silviculture.

Enggar Paramita worked as the communications officer for the AgFor project, 2012-2015. She has eight years' experience in communications, ranging from advertising through to development communications. She completed her bachelor degree in communications at Universitas Indonesia and is pursuing her master degree at the University of Queensland, Australia focusing on Communications for Social Change.

James M. Roshetko is an agroforestry systems scientist with ICRAF, leader of the Southeast Asia Trees and Market Unit and senior team leader of the AgFor project. His research interests focus on smallholder tree-based systems as viable agricultural and natural resources management systems that contribute significantly to local livelihoods' objectives and global environmental goals. He has a doctorate in Geosciences and Natural Resource Management from the University of Copenhagen and a master of science in Forest and Agroforestry Management from Michigan State University. 


\section{Abstract}

This study was conducted to identify potential information channels for disseminating agroforestry innovations at village level in South and Southeast Sulawesi provinces, Indonesia. An information channel is a method of transmitting information in a specific, oneway flow. In this study, an investigation of information channels from sources to users was conducted to understand the dissemination of innovative agroforestry practices. A better understanding of how farmers obtain information will enhance the impacts of any agricultural extension program. The study was conducted through semi-structured interviews with 144 farmers (40\% female) from 12 villages in two districts in South Sulawesi Province and two districts in Southeast Sulawesi Province. In each village, 12 respondents from various ethnicities were interviewed. Data collected during the study covered sources of information, type of information channel in disseminating agricultural/agroforestry information, and important disseminators. Results from the study identified four types of information channels, that is, 1) mass media; 2) personal contacts (interpersonal communication) through opinion leaders, extension agents and other reliable contacts, such as family and friends; 3 ) formal extension services or government programs; and 4) social gatherings, such as weddings and village meetings. Personal contacts (interpersonal communication) were considered the most accessible for farmers. We also found that opinion leaders (who were also expert farmers) and government extension agents were the two major actors for disseminating agroforestry innovations. Interpersonal discussion with the agroforestry disseminators was the most preferred information channel. Formal extension services were considered as the most reliable channel for disseminating agroforestry innovations, however, the services were limited and mostly occurred only in areas with better infrastructure. Providing agroforestry extension services in villages will also enhance women's access to agricultural information. In areas where language is a barrier, involving farmers as extension agents is recommended.

\section{Keywords}

Opinion leaders, extension agents, South Sulawesi, Southeast Sulawesi, mass media, interpersonal. 


\section{Acknowledgements}

This study was supported by the Agroforestry and Forestry: Linking Knowledge to Action project funded by the Department of Foreign Affairs, Trade and Development, Government of Canada (Contribution Arrangement No. 7056890). We appreciate the assistance and contribution of the collaborating communities and local government offices in Bantaeng and Bulukumba districts, South Sulawesi; and Konawe and Kolaka districts, Southeast Sulawesi. We are greatly acknowledged the inputs and contribution on this study from Mr Robert Finlayson, regional communications specialist, ICRAF Southeast Asia. 


\section{Contents}

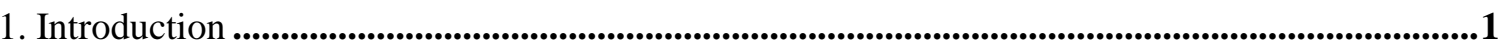

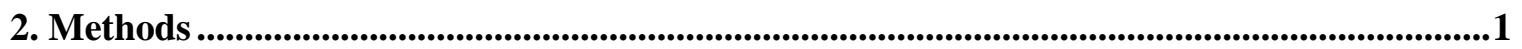

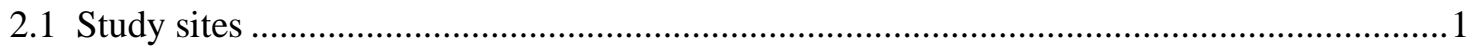

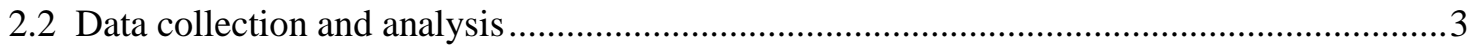

3. Findings .......................................................................................................................................................

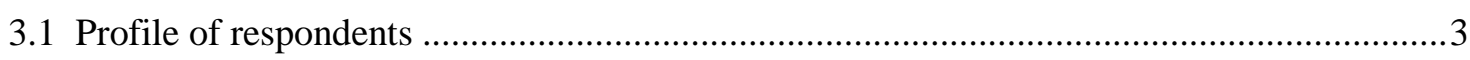

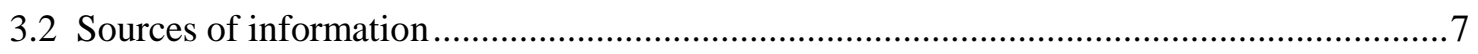

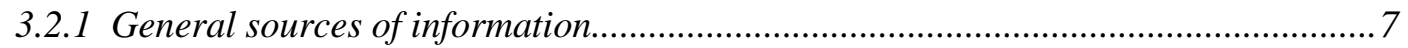

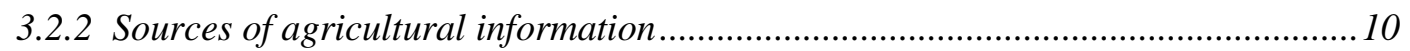

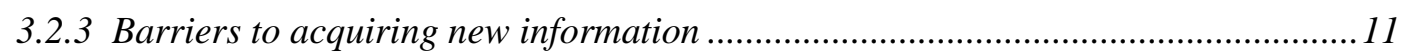

3.2.4 Preferred communication methods for acquiring new information ......................... 12

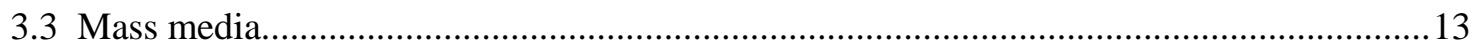

3.3.1 Most accessible communications media ……............................................................ 13

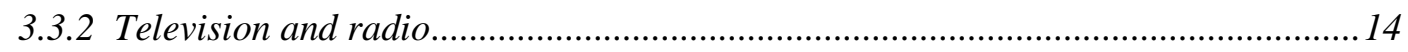

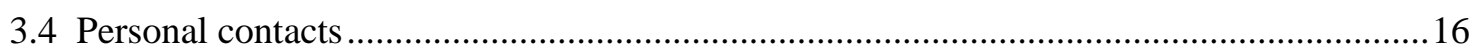

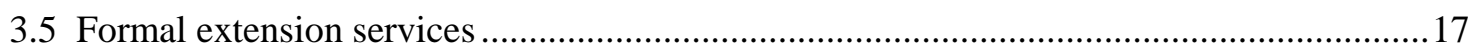

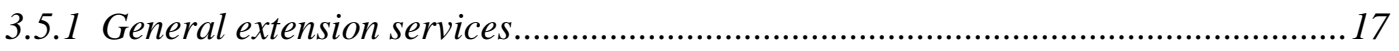

3.5.2 Preferences for agricultural extension methods .................................................... 18

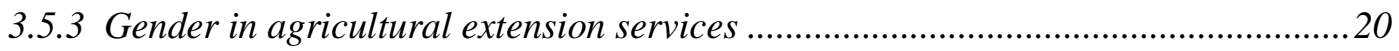

3.5.4 Agricultural extension communication media ............................................................2.

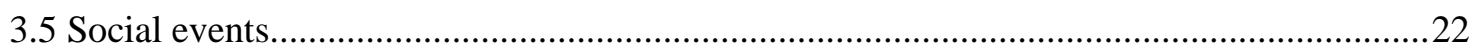

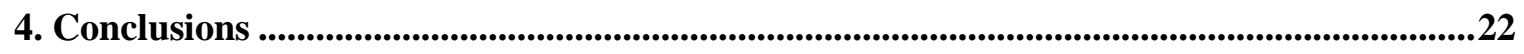

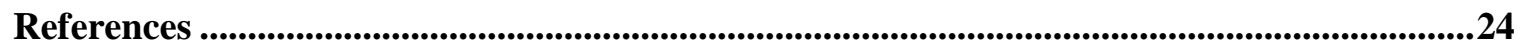




\section{List of Tables}

Table 1. Characteristics of study districts in South and Southeast Sulawesi provinces, Indonesia

Table 2. Characteristics of study villages in South and Southeast Sulawesi provinces 3

Table 3. Sources of general information in South and Southeast Sulawesi provinces, percentage of total respondents per village class per province

\section{List of Figures}

Figure 1. Map of study locations in South and Southeast Sulawesi provinces of Indonesia (marked with yellow circles).

Figure 2. Types of land uses of respondents in South and Southeast Sulawesi provinces, Indonesia

Figure 3. Length of formal education of the respondents per village in South and Southeast Sulawesi provinces

Figure 4. Dominant ethnicity per village by distance to district capital (near, intermediate, far).

Figure 5. Reasons for migration in South and Southeast Sulawesi provinces

Figure 6. Gendered percentage of total types of information usually obtained per village classes in South and Southeast Sulawesi provinces

Figure 7. Ratio number of sources of information by internal to external sources based on respondents' length of education.

Figure 8. Ratio number of sources of information by internal to external sources across different ethnicities

Figure 9. Respondents' perspectives on the most reliable and accessible sources of agricultural information in South and Southeast Sulawesi provinces

Figure 10. Barriers to acquiring new information by village category based on distance to district capital (near, intermediate, far) in South and Southeast Sulawesi provinces

Figure 11. Communication methods used in acquiring new knowledge, by gender, in South and Southeast Sulawesi provinces

Figure 12. Communications media owned by respondents in South and Southeast Sulawesi provinces

Figure 13. Preferred radio and television stations in South and Southeast Sulawesi provinces

Figure 14. Schedule of preferred radio and television shows in South and Southeast Sulawesi provinces

Figure 15. Types of agricultural information sought by farmers from opinion leaders 
Figure 16. Respondents who received extension services in the past 5 years in South and Southeast Sulawesi

Figure 17. Preferences for effective agricultural extension methods based on respondents' perceptions by gender (men, women) and category of village (near, intermediate, far) in South and Southeast Sulawesi provinces

Figure 18. Preferences for effective agricultural extension methods based on respondents' perception by gender and by ethnicities in South and Southeast Sulawesi provinces

Figure 19. Participation by gender in agricultural extension events in South and Southeast Sulawesi 


\section{Introduction}

An information channel is a method of transmitting information in a specific, one-way flow, for example from sources to users or from users to sources. Village information channels can be used by extension agents when planning cost-effective activities to disseminate an agricultural innovation. Utilizing preferred information channels for implementing an activity or sharing information about a new technology enhances community participation and adoption. For disseminating information about an innovation, identifying channels from sources to users is recommended; while for facilitating the generation of an innovation it is necessary to identify both channels from sources to users and from users to sources. This study analyzes the information channel from sources to users that are used to disseminate agricultural and agroforestry innovations.

In many parts of Indonesia, the process of disseminating agricultural innovation is dominated by a 'top-down' approach, with government extension agents as the main disseminators of innovations. However, in the past 10 years, the government has promoted a more 'bottom-up' approach in which extension agents have to identify a community's extension needs and report those needs to the head of the district extension office at their annual planning meeting. Because there are a limited number of extension agents, and an even smaller number of those who conduct baseline studies to identify information channels before they plan agricultural extension activities, the adoption of the bottom-up approach and participation by villages remains low. Thus, information about which channels are preferred by farmers is also limited.

Identifying information channels is not only useful for government extension agencies but also for projects that want to improve agricultural production and enhance farmers' livelihoods, such as the Agroforestry and Forestry in Sulawesi: Linking Knowledge with Action (AgFor) project implemented by the World Agroforestry Centre with funding from the Department of Foreign Affairs, Trade and Development, Canada. The AgFor project has the goal of empowering motivated farmers of both genders to enhance and diversify the productivity and profitability of their tree-based systems in a sustainable manner. A series of baseline studies was conducted to document the positive impact of the project (Martini et al 2012; Janudianto et al 2012; Khususiyah et al 2012; Mulyoutami et al 2012). The study reported in this working paper is part of this series. The objective of the study was to analyze the options of information channels in villages for disseminating agroforestry innovations.

\section{Methods}

\subsection{Study sites}

The study was conducted from October to November 2012 in Bantaeng and Bulukumba districts of South Sulawesi Province and Konawe and East Kolaka districts of Southeast Sulawesi Province (Figure 1), which were AgFor project sites. 

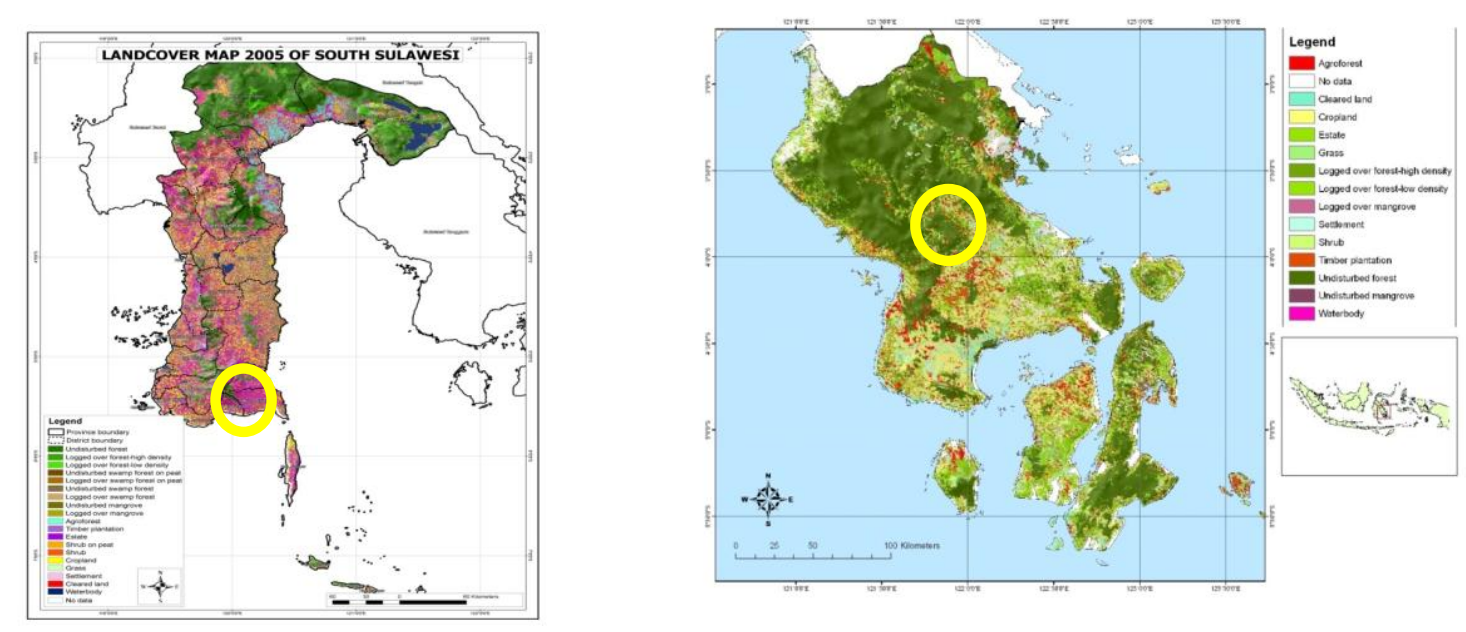

Figure 1. Map of study locations in South and Southeast Sulawesi provinces of Indonesia (marked with yellow circles).

Source: World Agroforestry Centre Indonesia, Spatial Analysis Unit, 2012

Sources of farmers' livelihoods in those districts were dominated by agroforestry systems of cacao, coffee, clove, durian, other tropical fruits and pepper as the main commodities (Janudianto et al 2012; Khususiyah et al 2012) (Table 1). Ethnic composition varied in the districts, from multi-ethnicity as was commonly found in Southeast Sulawesi through to double or single ethnicity as was the case in South Sulawesi. Indonesian was commonly used to communicate between ethnicities and had become the common language of the younger generations, with the exception of Bantaeng district. In Bantaeng, the common language spoken in villages was Makassarese. Infrastructure (electricity, telephone and road) and education levels varied between districts.

Table 1. Characteristics of study districts in South and Southeast Sulawesi provinces, Indonesia

\begin{tabular}{|c|c|c|c|}
\hline District, province & Sources of local livelihoods & $\begin{array}{l}\text { Dominant } \\
\text { ethnicity }\end{array}$ & $\begin{array}{l}\text { Common language } \\
\text { spoken by farmers }\end{array}$ \\
\hline $\begin{array}{l}\text { Bantaeng, South } \\
\text { Sulawesi }\end{array}$ & $\begin{array}{l}\text { Agriculture (irrigated rice, } \\
\text { vegetables, coffee, cacao, } \\
\text { clove, maize, coconut) }\end{array}$ & Makassarese & Makassarese, Konjo \\
\hline $\begin{array}{l}\text { Bulukumba, South } \\
\text { Sulawesi }\end{array}$ & $\begin{array}{l}\text { Agriculture (irrigated rice, } \\
\text { vegetables, coffee, cacao, } \\
\text { clove, maize, coconut) }\end{array}$ & $\begin{array}{l}\text { Makassarese, } \\
\text { Bugis }\end{array}$ & $\begin{array}{l}\text { Indonesian, } \\
\text { Makassarese, Konjo }\end{array}$ \\
\hline $\begin{array}{l}\text { Konawe, Southeast } \\
\text { Sulawesi }\end{array}$ & $\begin{array}{l}\text { Agriculture (cacao, pepper, } \\
\text { coconut) }\end{array}$ & $\begin{array}{l}\text { Tolaki, Bugis, } \\
\text { Javanese, } \\
\text { Balinese }\end{array}$ & Indonesian \\
\hline $\begin{array}{l}\text { East Kolaka, } \\
\text { Southeast Sulawesi }\end{array}$ & $\begin{array}{l}\text { Agriculture (cacao, pepper, } \\
\text { coconut) }\end{array}$ & $\begin{array}{l}\text { Tolaki, Bugis, } \\
\text { Toraja, Balinese }\end{array}$ & Indonesian \\
\hline
\end{tabular}




\subsection{Data collection and analysis}

Data was collected through semi-structured interviews in 12 villages in four districts. In each district, three villages were selected based on their distance from the district capital, representing the local centre of agricultural information (Table 2). Interviews were conducted with 12 respondents per village, consisting of 10 farmers (five men and five women) and two opinion leaders. Total number of respondents was 144 farmers (72 in South Sulawesi and 72 in Southeast Sulawesi, of whom $40 \%$ were female).

The socioeconomic background of each respondent, such as age, education level, main occupation and ethnicity, was recorded during the interview. Other information that was collected were sources of information, social activities used as a medium for exchanging new information, mass media commonly used in obtaining agricultural information, actors or disseminators in the village, types of information channels typically used to disseminate agricultural innovations, and preferred information channels for disseminating agricultural innovations. The data was analyzed qualitatively as well as quantitatively via descriptive statistics.

Table 2. Characteristics of study villages in South and Southeast Sulawesi provinces

\begin{tabular}{|c|c|c|c|c|c|c|}
\hline $\begin{array}{l}\text { District, } \\
\text { province }\end{array}$ & Study village & $\begin{array}{l}\text { Distance to } \\
\text { district } \\
\text { centre }\end{array}$ & $\begin{array}{l}\text { Migration } \\
\text { in and out }\end{array}$ & Electricity & $\begin{array}{l}\text { Phone } \\
\text { signal }\end{array}$ & $\begin{array}{l}\text { Road } \\
\text { accessibility }\end{array}$ \\
\hline \multirow{3}{*}{$\begin{array}{l}\text { Bantaeng, } \\
\text { South } \\
\text { Sulawesi }\end{array}$} & Pattaneteang & Far & Medium & Yes & Strong & Good \\
\hline & Kayu Loe & Intermediate & Low & No & Weak & Good \\
\hline & $\begin{array}{l}\text { Bonto } \\
\text { Bulaeng }\end{array}$ & Near & Medium & No & Weak & Good \\
\hline \multirow{3}{*}{$\begin{array}{l}\text { Bulukumba, } \\
\text { South } \\
\text { Sulawesi }\end{array}$} & Tana Toa & Far & Medium & No & Weak & Medium \\
\hline & Ara & Intermediate & High & Yes & Strong & Good \\
\hline & Tugondeng & Near & Medium & Yes & Strong & Good \\
\hline \multirow{3}{*}{$\begin{array}{l}\text { Konawe, } \\
\text { Southeast } \\
\text { Sulawesi }\end{array}$} & Ambondiaa & Far & Low & No & No & Poor \\
\hline & Lawonua & Intermediate & Medium & Yes & Weak & Medium \\
\hline & Wonua Hoa & Near & Medium & No & Weak & Medium \\
\hline \multirow{3}{*}{$\begin{array}{l}\text { East Kolaka, } \\
\text { Southeast } \\
\text { Sulawesi }\end{array}$} & Tinondo & Far & Low & No & No & Medium \\
\hline & Taosu & Intermediate & Medium & Yes & Weak & Good \\
\hline & Tasahea & Near & Medium & Yes & Yes & Good \\
\hline
\end{tabular}

\section{Findings}

\subsection{Profile of respondents}

Respondents in this study were smallholding farmers. Male respondents had an average age of 43 years and women 36 years. Twenty-seven percent $(27 \%)$ of the respondents were village leaders/opinion leaders. Most of the respondents owned agricultural land; only $10 \%$ of respondents did not (Figure 2). 


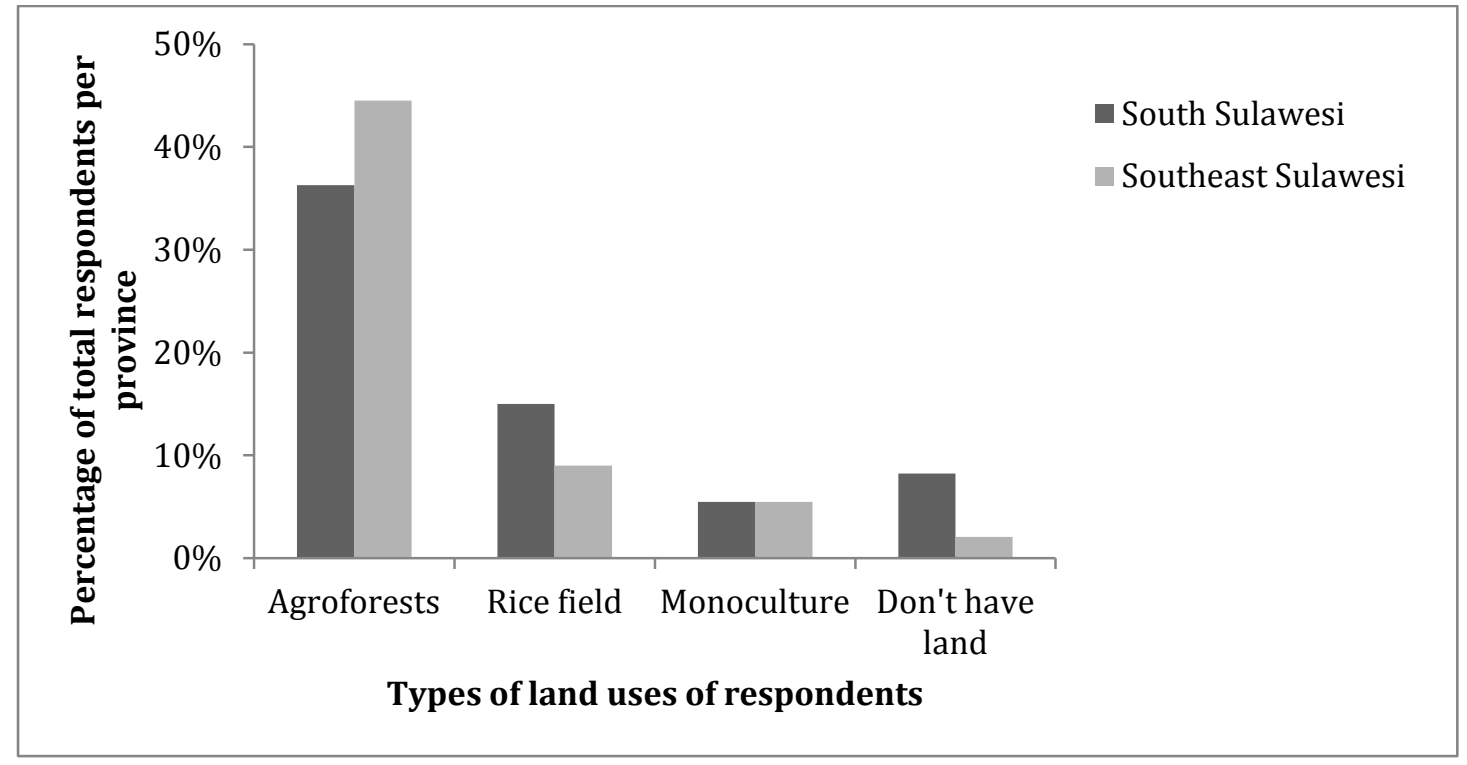

Figure 2. Types of land uses of respondents in South and Southeast Sulawesi provinces, Indonesia

Respondents' membership in farmers' groups was higher in Southeast Sulawesi (33.5\%) compared to South Sulawesi (22.0\%). This was mostly because in Southeast Sulawesi there were many projects related to enhancement of cacao production, which required farmers to be in groups to receive agricultural aid.

On average, the education level of the respondents in both provinces was elementary school. Respondents in South Sulawesi had lower levels of education compared to Southeast Sulawesi. Distance from the village to the district's capital had no strong correlation with respondents' level of education, although villagers near the district capital tended to have higher education levels (Figure 3.). 


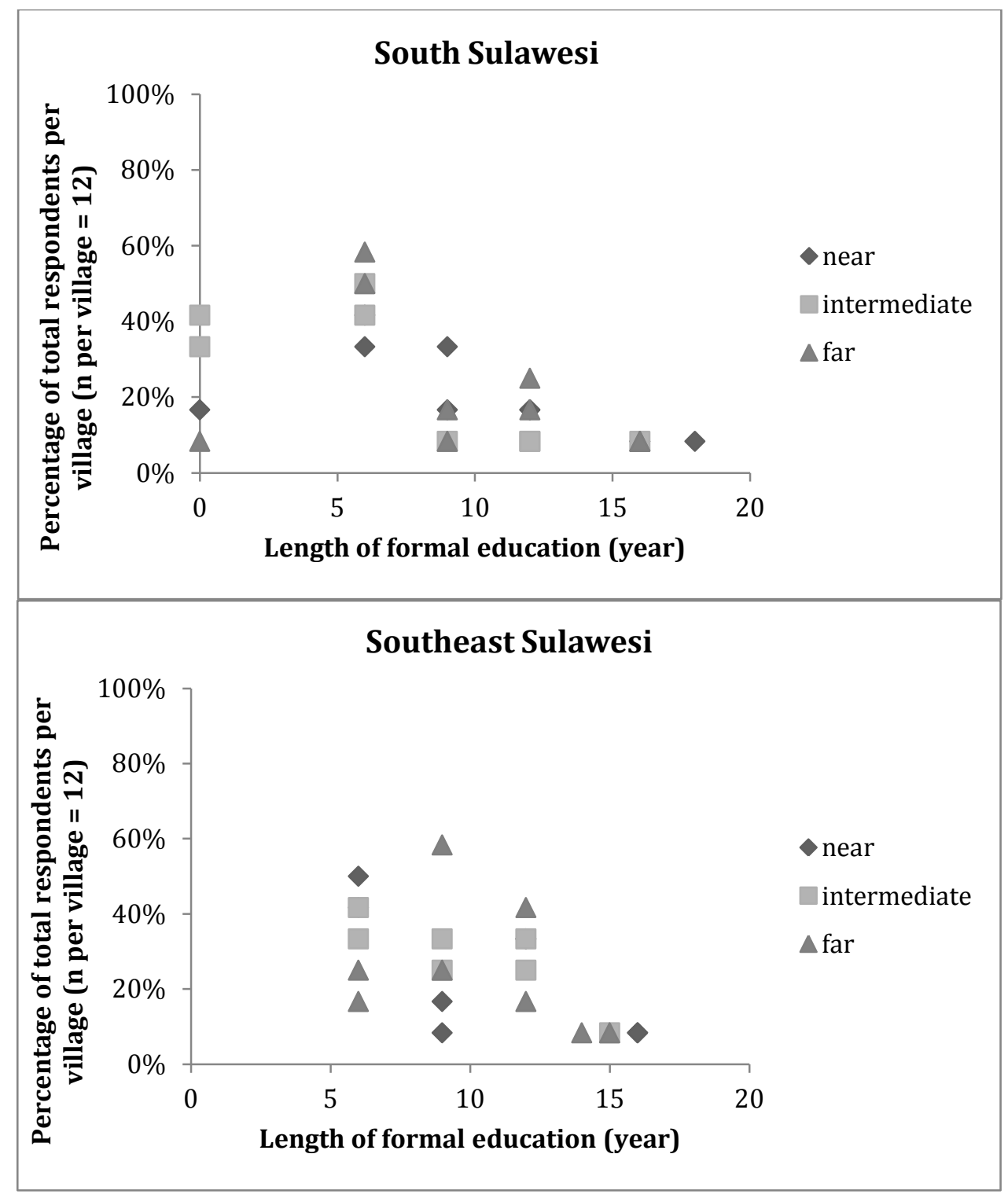

Figure 3. Length of formal education of the respondents per village in South and Southeast Sulawesi provinces

In South Sulawesi, the dominant ethnicities were Makassarese, Bugis and Konjo, while in Southeast Sulawesi they were Tolaki and Bugis. Javanese, Balinese and Sundanese were also present (Figure 4.). There were no significant differences in ethnicity proportion between village classes (near, intermediate and far) in either province. 


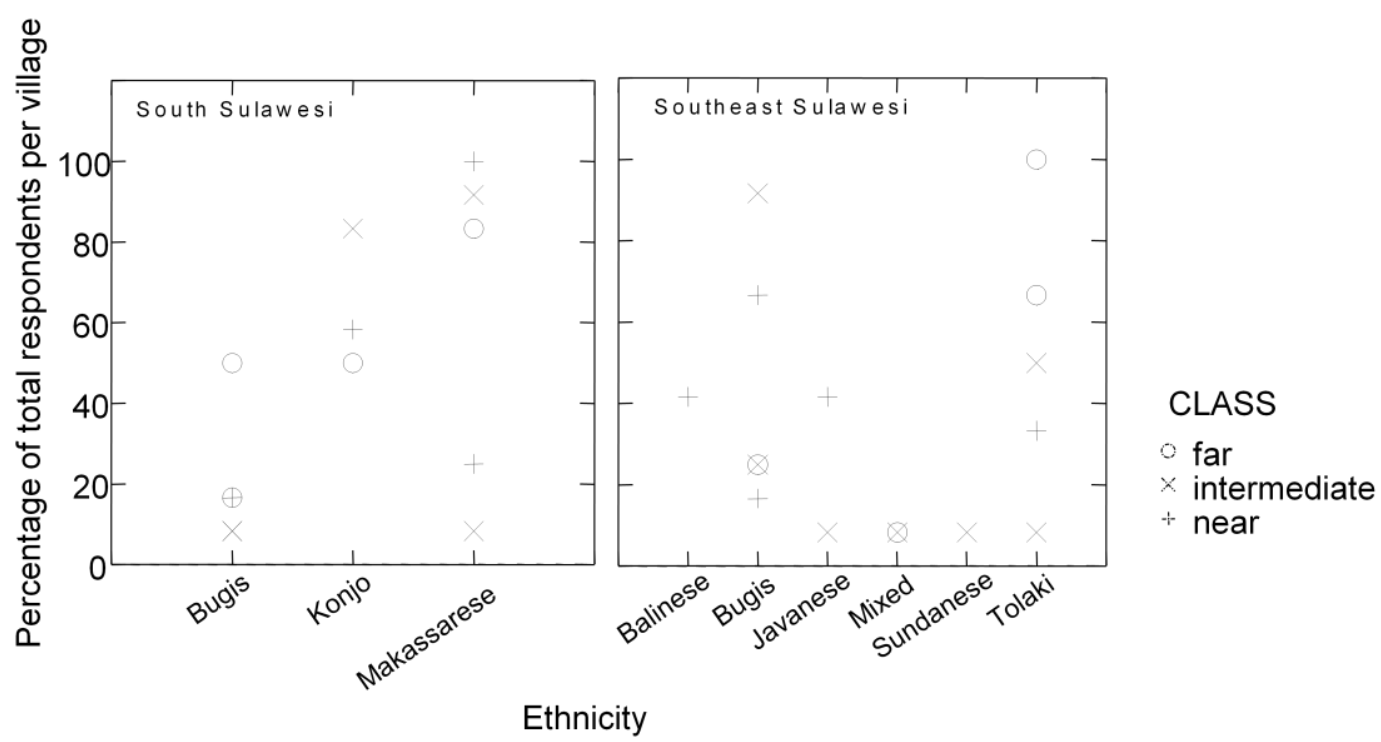

Figure 4. Dominant ethnicity per village by distance to district capital (near, intermediate, far)

At the study sites, $48.6 \%$ of respondents were migrants who had arrived in their current location 11-to-18 years ago. The number of male migrants was higher (29.9\% of total respondents) than female (18.8\%). In total, the number of migrants was higher in Southeast Sulawesi $(37.5 \%)$ than South Sulawesi (11.1\%). The reason for migration was mainly marriage in South Sulawesi and livelihoods' opportunities in Southeast Sulawesi (Figure 5).

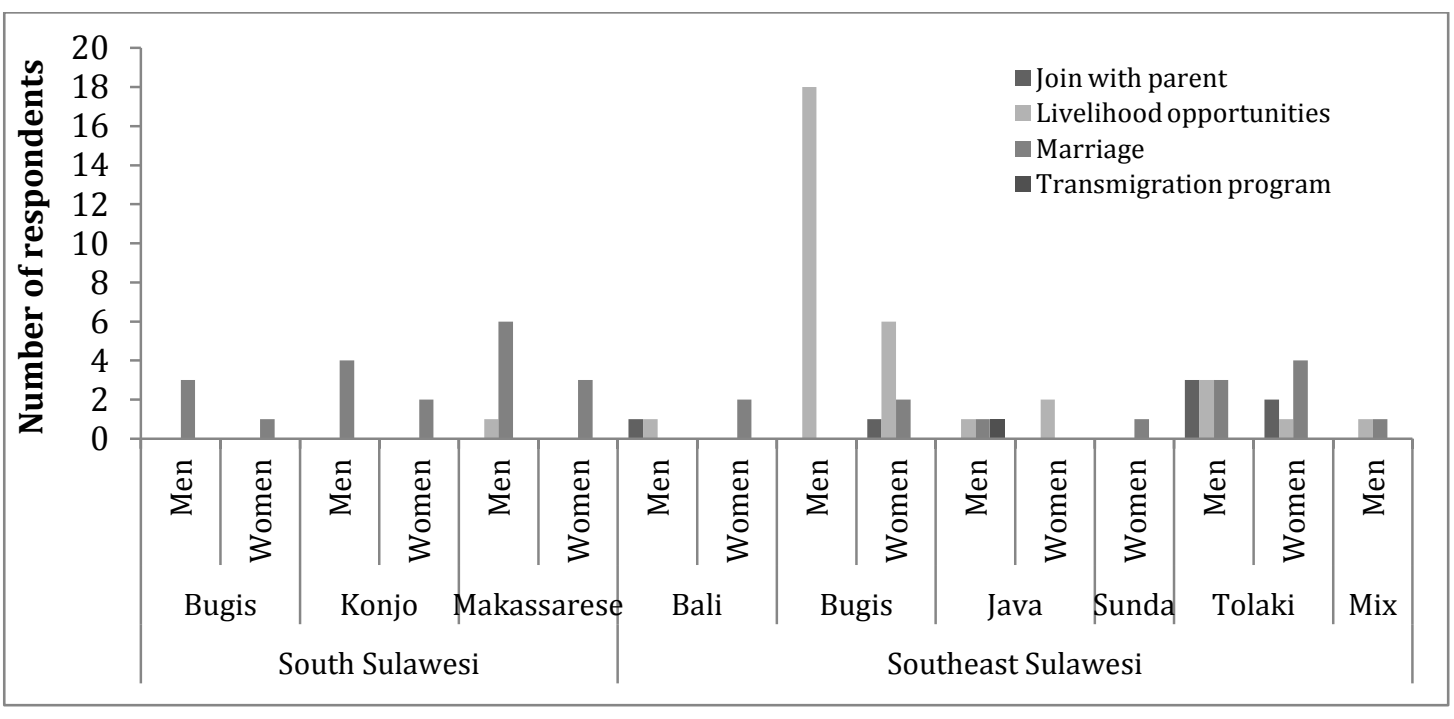

Figure 5. Reasons for migration in South and Southeast Sulawesi provinces

In our study areas, generally, opinion leaders in each village were people of the dominant ethnicity. The education level of opinion leaders was on average above elementary school with the ability to speak fluent Indonesian (the national language). On average, the age of opinion leaders was above 40 years-old. Some opinion leaders were migrants who had lived 
in the area for more than 20 years. All of the opinion leaders were members of farmers' groups.

\subsection{Sources of information}

\subsubsection{General sources of information}

General information about agriculture, health, education, marketing, public administration and other topics was obtained by respondents both from inside and outside the village with a higher proportion obtaining information from outside the village (external), that is, $52 \%$ of total respondents. Inside the village, sources of information (internal) were opinion leaders, friends, farmers, farmers' groups, family, community meetings, religious groups and village traders. External sources of information were mass media, government, traders, friends from other villages, farmers from other villages, traders from other villages, private companies, projects, libraries, markets, migration activity and opinion leaders from other villages. Between provinces, there was no significant difference in sources of information. Distance of the village from the district capital was not clearly correlated with respondents' intensity in obtaining information (Table 3).

Table 3. Sources of general information in South and Southeast Sulawesi provinces, percentage of total respondents per village class per province

\begin{tabular}{|c|c|c|c|c|c|c|}
\hline \multirow[b]{2}{*}{$\begin{array}{l}\text { Sources of general } \\
\text { information }\end{array}$} & \multicolumn{2}{|c|}{ South Sulawesi (\%) } & \multicolumn{4}{|c|}{ Southeast Sulawesi (\%) } \\
\hline & $\begin{array}{l}\text { Near } \\
(n=24)\end{array}$ & $\begin{array}{l}\text { Inter- } \\
\text { mediate } \\
(n=24)\end{array}$ & $\begin{array}{l}\text { Far } \\
(n=24)\end{array}$ & $\begin{array}{l}\text { Near } \\
(n=24)\end{array}$ & $\begin{array}{l}\text { Inter- } \\
\text { mediate } \\
(n=24)\end{array}$ & $\begin{array}{l}\text { Far } \\
(n=24)\end{array}$ \\
\hline \multicolumn{7}{|l|}{ Internal } \\
\hline Community meetings & 1.1 & 6.3 & 4.1 & N.A. & 1.1 & N.A. \\
\hline Family & 5.5 & 5 & 2 & 7.5 & 3.4 & 8.5 \\
\hline Farmers' groups & 2.2 & 6.3 & 1 & 5 & 5.7 & 3.2 \\
\hline Farmers & 2.2 & 6.3 & 4.1 & 7.5 & 5.7 & 4.3 \\
\hline Friends & 8.8 & 12.5 & 12.2 & 7.5 & 9.1 & 11.7 \\
\hline Opinion leaders & 19.8 & 17.5 & 14.3 & 15 & 10.2 & 11.7 \\
\hline Religious groups & 1.1 & N.A. & N.A. & N.A. & 1.1 & N.A. \\
\hline Traders & 1.1 & 2.5 & 3.1 & N.A. & N.A. & N.A. \\
\hline Total percentage & 41.8 & 56.4 & 40.8 & 42.5 & 36.3 & 39.4 \\
\hline \multicolumn{7}{|l|}{ External } \\
\hline $\begin{array}{l}\text { Family from other } \\
\text { villages }\end{array}$ & N.A. & N.A. & 1 & 2.5 & 2.3 & 1.1 \\
\hline $\begin{array}{l}\text { Farmers from other } \\
\text { villages }\end{array}$ & 3.3 & N.A. & N.A. & N.A. & N.A. & N.A. \\
\hline $\begin{array}{l}\text { Friends from other } \\
\text { villages }\end{array}$ & N.A. & N.A. & 1 & N.A. & N.A. & 1.1 \\
\hline Government & 20.9 & 18.8 & 19.4 & 18.8 & 23.9 & 20.2 \\
\hline Libraries & 1.1 & 1.3 & 2 & 2.5 & 1.1 & 1.1 \\
\hline Markets & 2.2 & 2.5 & 1 & N.A. & N.A. & N.A. \\
\hline Mass media & 25.3 & 18.8 & 28.6 & 23.8 & 27.3 & 36.2 \\
\hline
\end{tabular}




\begin{tabular}{|c|c|c|c|c|c|c|}
\hline \multirow[b]{2}{*}{$\begin{array}{l}\text { Sources of general } \\
\text { information }\end{array}$} & \multicolumn{3}{|c|}{ South Sulawesi (\%) } & \multicolumn{3}{|c|}{ Southeast Sulawesi (\%) } \\
\hline & $\begin{array}{l}\text { Near } \\
(n=24)\end{array}$ & $\begin{array}{l}\text { Inter- } \\
\text { mediate } \\
(\mathrm{n}=24)\end{array}$ & $\begin{array}{l}\text { Far } \\
(n=24)\end{array}$ & $\begin{array}{l}\text { Near } \\
(n=24)\end{array}$ & $\begin{array}{l}\text { Inter- } \\
\text { mediate } \\
(n=24)\end{array}$ & $\begin{array}{l}\text { Far } \\
(n=24)\end{array}$ \\
\hline Migration activity & N.A. & N.A. & 3.1 & N.A. & N.A. & N.A. \\
\hline $\begin{array}{l}\text { Opinion leaders from } \\
\text { other villages }\end{array}$ & N.A. & N.A. & N.A. & 1.3 & N.A. & N.A. \\
\hline Private companies & 2.2 & N.A. & N.A. & N.A. & 2.3 & N.A. \\
\hline Projects & 2.2 & N.A. & 2 & 8.8 & 5.7 & 1.1 \\
\hline $\begin{array}{l}\text { Traders from other } \\
\text { villages }\end{array}$ & 1.1 & 2.5 & 1 & N.A. & 1.1 & N.A. \\
\hline Total percentage & 58.3 & 43.9 & 59.1 & 57.7 & 63.7 & 60.8 \\
\hline
\end{tabular}

Respondents frequently accessed information from family, farmers' groups, farmers, friends, government, libraries, markets, mass media, opinion leaders and traders. Sources of information that were not frequently accessed were colleagues from other villages, private companies and projects.

From a gender perspective, at most of the sites men tended to more frequently obtain information externally (Figure 6). An exception was for village class 'intermediate' in South Sulawesi Province, where women tended to have greater access to external information because they were workers (share labour or off-farm jobs) in areas outside their own village.

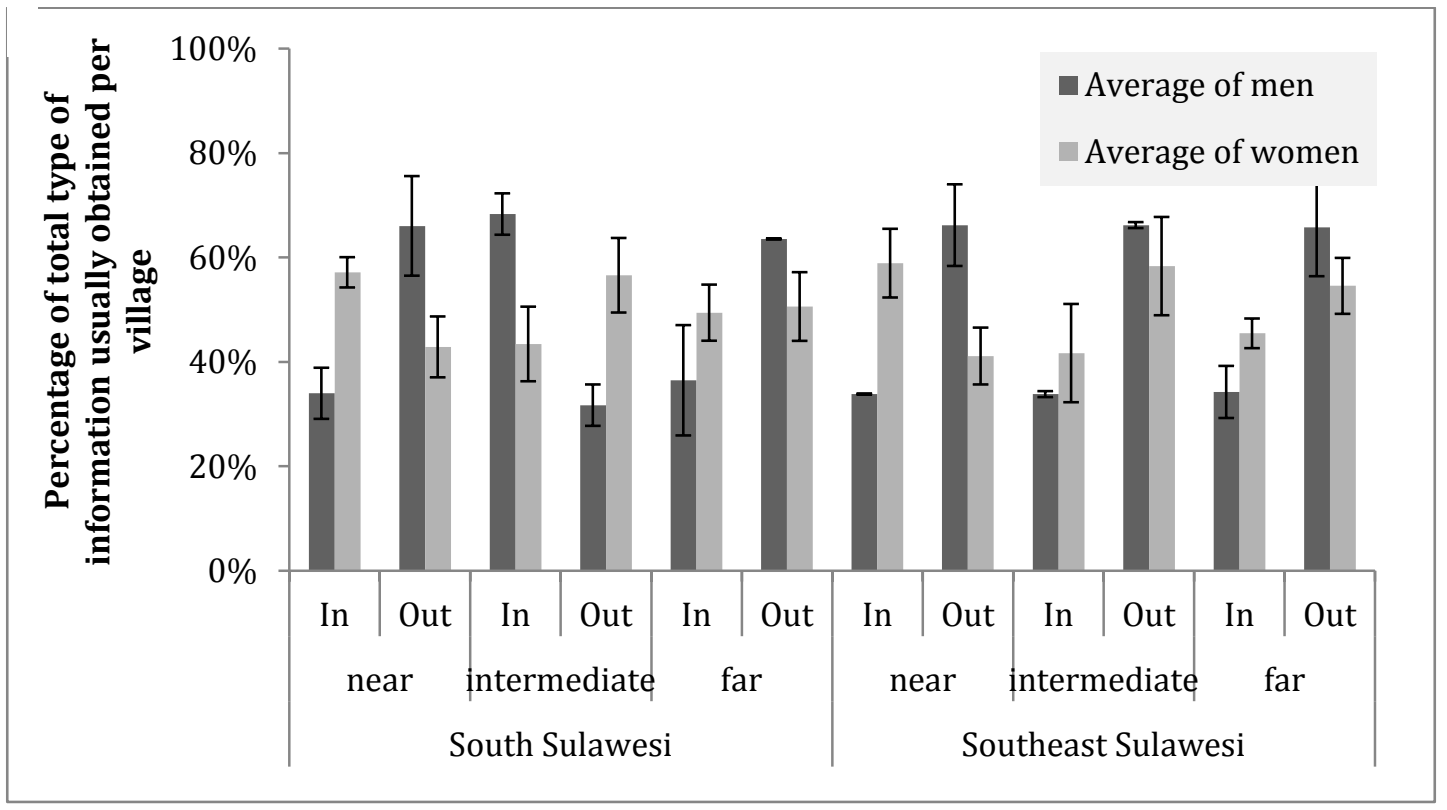

Note: In = internal; Out = external; the error bars is for the standard errors of mean .

Figure 6. Gendered percentage of total types of information usually obtained per village classes in South and Southeast Sulawesi provinces 
In both provinces, the level of formal education was not correlated to how villagers obtained information (Figure 7). At all study sites, the ratio number of sources of internal information to external was higher for women than men, meaning that compared to men, women obtained information more from internal sources than externally. Specifically for South Sulawesi, respondents who never attended school tended to search for information from sources internally. These people tended to stay in the village and had limited ability in speaking Indonesian.

For all ethnicities, men tended to access more information externally (Figure 8). When comparing gender by ethnicity, only Balinese, Javanese and Konjo women depended solely on sources of internal information, particularly, from their family (husband, father and brothers).

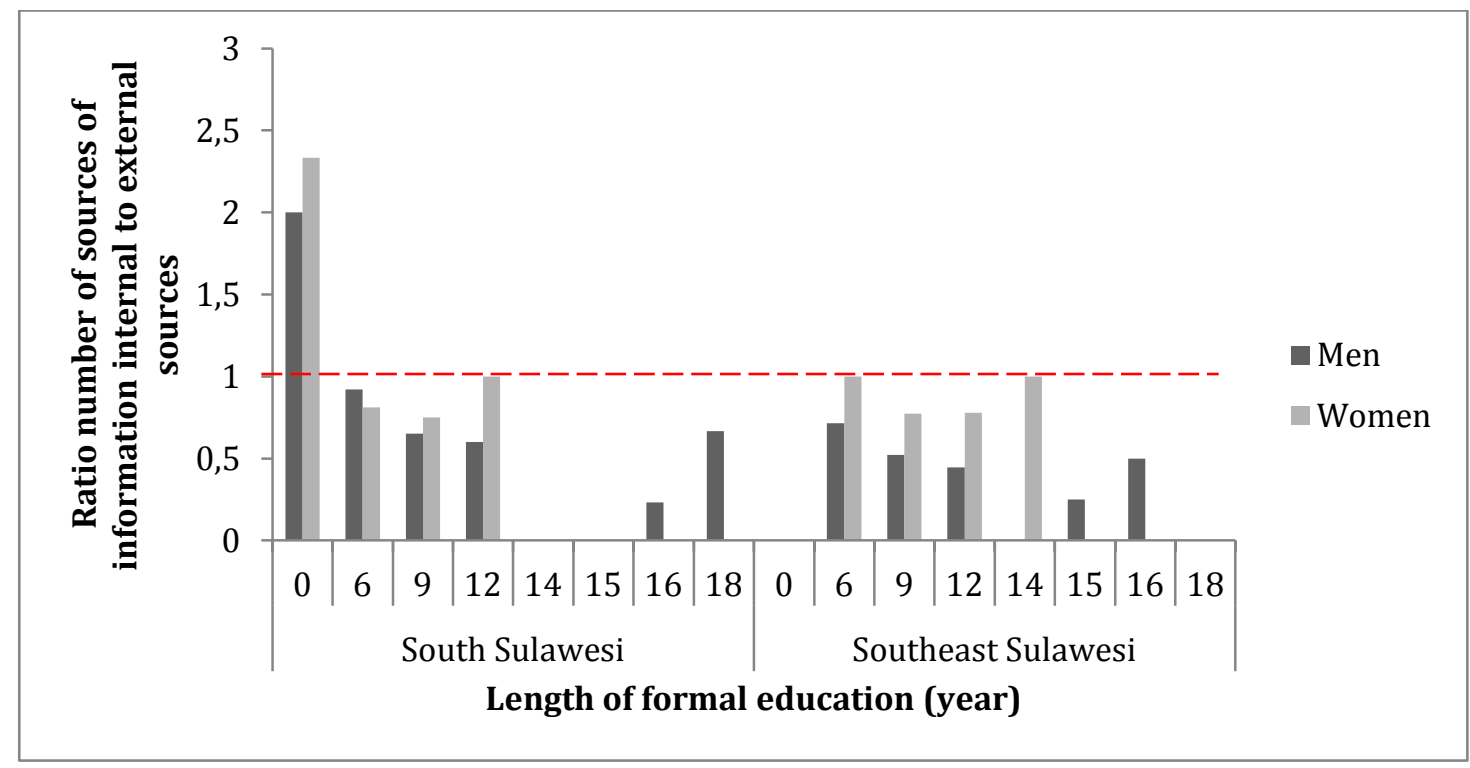

Note: Ratio value higher than 1 means that internal sources of information were used more frequently than external sources.

Figure 7. Ratio number of sources of information by internal to external sources based on respondents' length of education. 


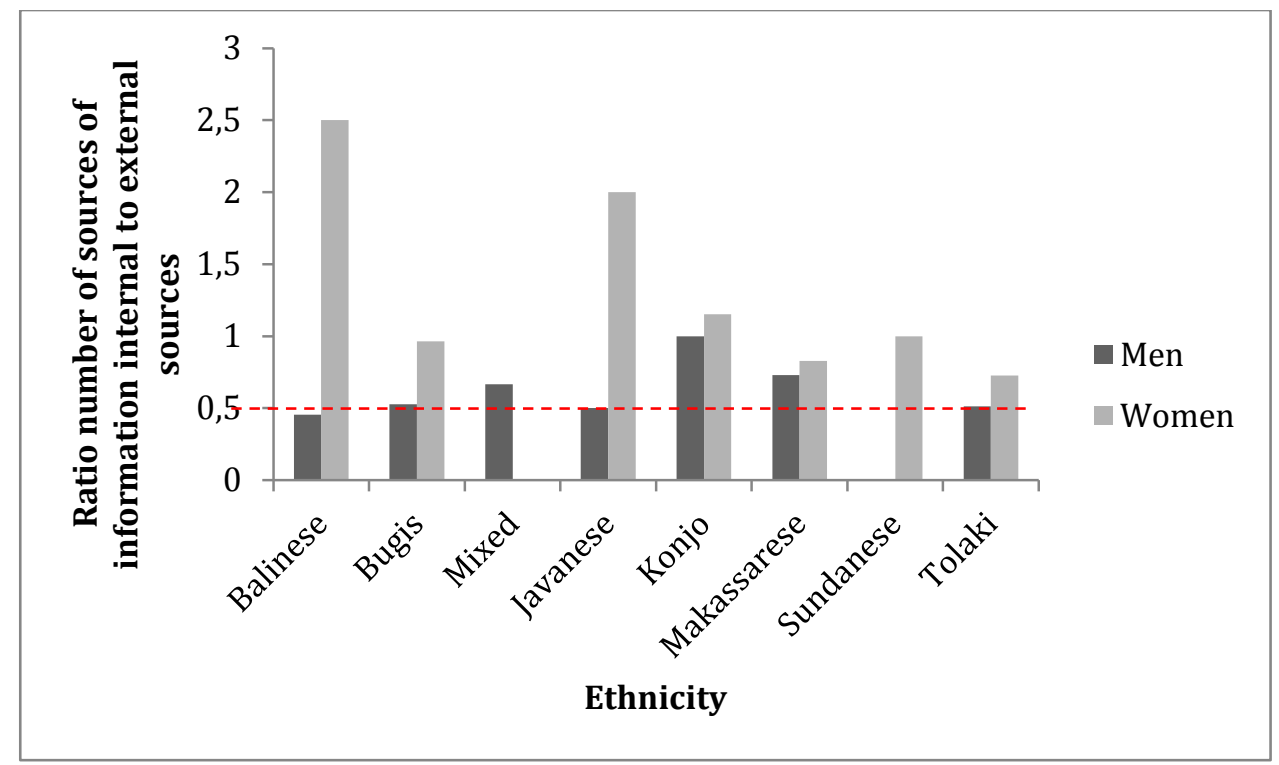

Note: Ratio value higher than 1 means that internal sources of information were used more frequent than external sources.

Figure 8. Ratio number of sources of information by internal to external sources across different ethnicities

\subsubsection{Sources of agricultural information}

Agricultural information was mostly obtained from the same sources as general information, that is, farmers inside the village, extension agents, family, farmers from outside the village, opinion leaders, mass media, projects and NGOs or students. Additionally, own experiments also become source of agricultural information. Respondents reported that they most frequently searched for information on 1) cultivation and domestication of important crops; 2) prices of marketable agricultural products; 3 ) types of new agricultural commodities; 4) good agricultural management practices to increase production; 5) new technology for garden maintenance (including fertilizing); 6) technologies for pest and diseases management; and 7) cacao side-grafting technique.

Based on the discussion with respondents in South Sulawesi, reliable and accessible sources of agricultural information were extension agents, farmers from the same village, opinion leaders, family, mass media, farmers from other villages, own experiments, NGOs/students, and projects, in descending order of magnitude (Figure 9). In Southeast Sulawesi, which had limited visits by extension agents, farmers from the same village were considered the most reliable and accessible sources of agricultural information. Poor road conditions and inaccessibility of villages limited visits by extension agents in Southeast Sulawesi. 


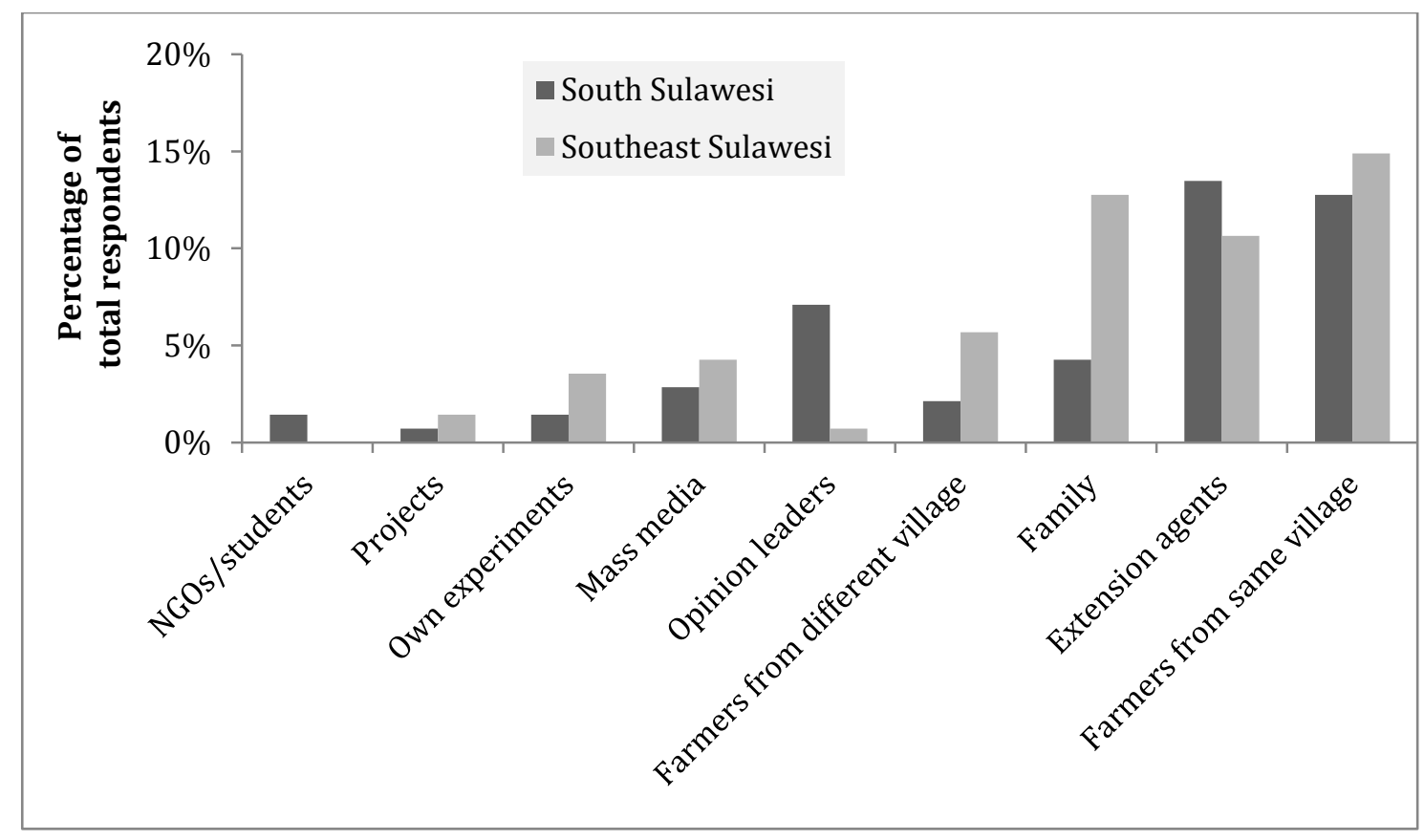

Figure 9. Respondents' perspectives on the most reliable and accessible sources of agricultural information in South and Southeast Sulawesi provinces

\subsubsection{Barriers to acquiring new information}

Based on the respondents' perspectives, barriers to acquiring new information were 1) location of the village (level of isolation); 2) limited media for communication between villagers; 3 ) limited support from local governments in providing or improving community access to information; 4) never invited to extension services' events; 5) rarely met extension agents; and 6) illiterate or not able to speak Indonesian (Figure 10). In Southeast Sulawesi, villages located far from the district capital rarely received visits from extension agents owing to poor road accessibility. Frequency of extension agents' visits tended to decrease with distance of the village from the district capital, meaning that villages far from the capital received less visits compared to those nearer. 


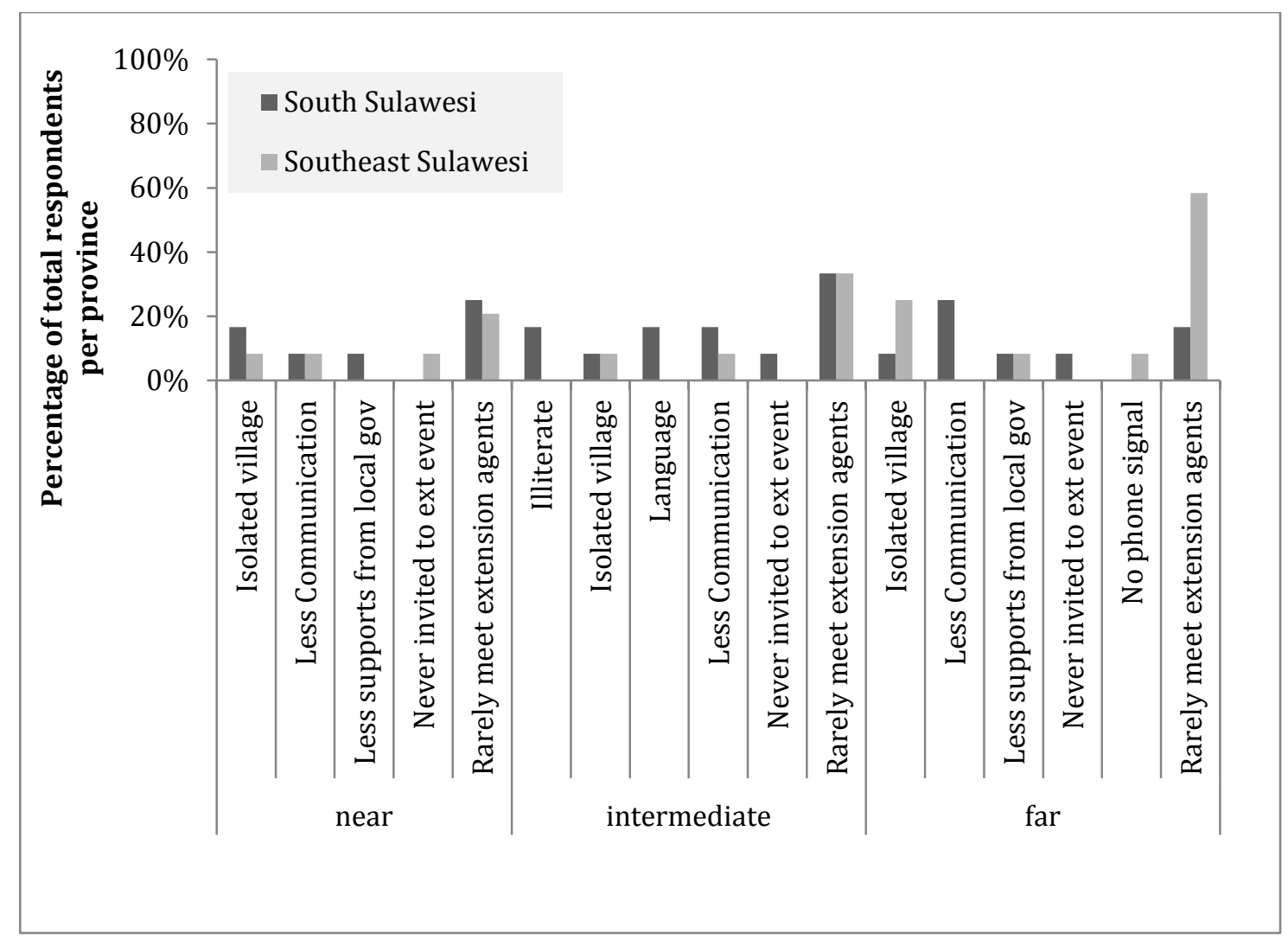

Figure 10. Barriers to acquiring new information by village category based on distance to district capital (near, intermediate, far) in South and Southeast Sulawesi provinces

\subsubsection{Preferred communication methods for acquiring new information}

During the survey, we set out to identify respondents' preferences for the methods of acquiring new information by asking a pair-wise comparison of six possible methods, that is, reading, listening, observing, audiovisual (for example, television), one-on-one discussion and practice. We gave a score of 1 to the preferred method. Subsequently, the scores of each method were summed and compared by averaging the results and calculating standard errors.

The results showed no significant difference between provinces (Figure 11), however, in South Sulawesi reading was least preferred owing to a higher number of illiterate respondents. Reading was only preferred by respondents with a level of formal education above high school, while listening was more preferred by respondents with levels of education at elementary school and below. In both provinces, when comparing genders, women tended to prefer listening, observing and watching television while men tended to prefer one-on-one discussions and self-experience for acquiring new information. 


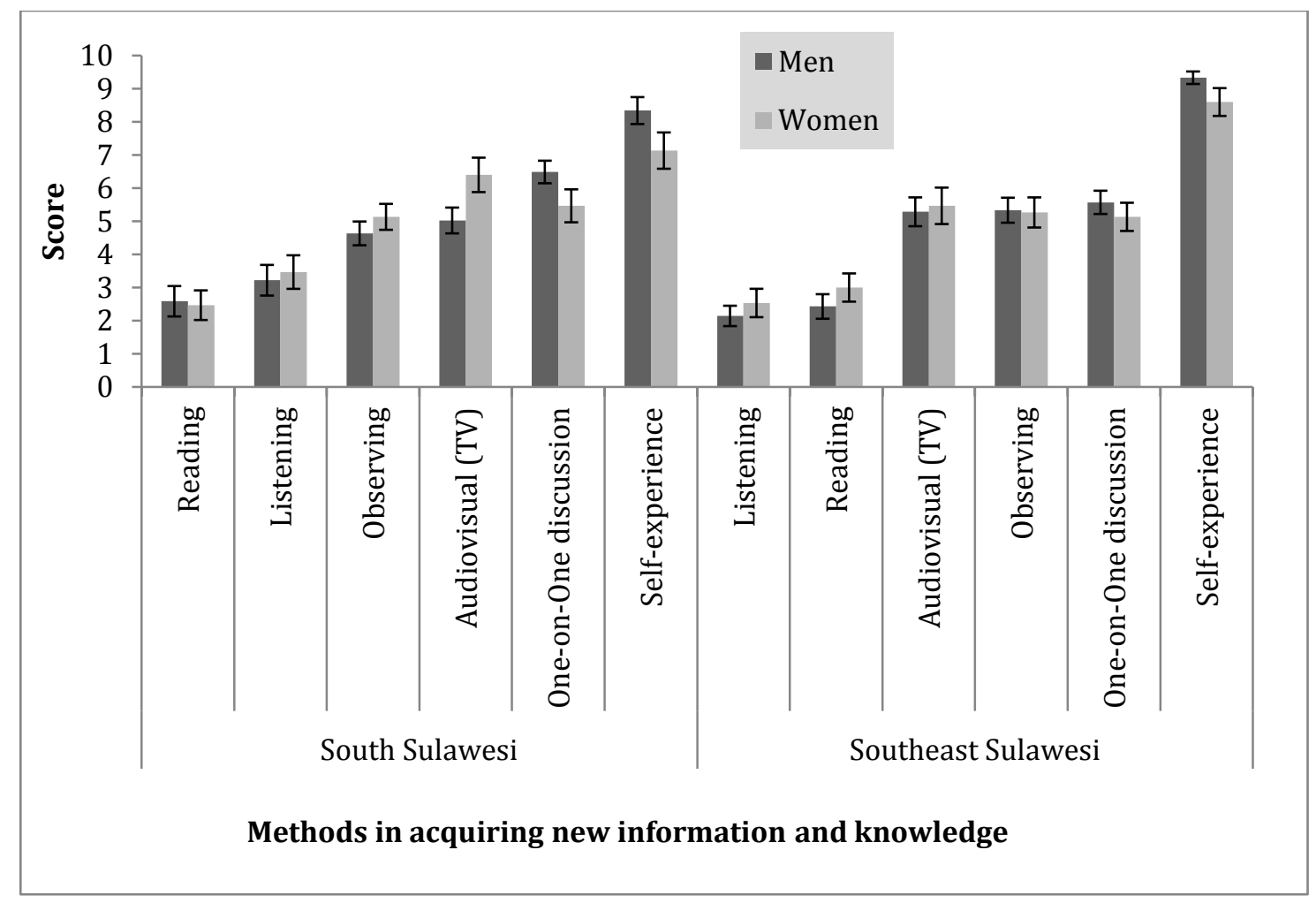

Note: the error bars are for the standard errors of mean.

Figure 11. Communication methods used in acquiring new knowledge, by gender, in South and Southeast Sulawesi provinces

\subsection{Mass media}

\subsubsection{Most accessible communications media}

In both provinces, mobile phones were the most accessible communications media, owned by more than $80 \%$ of total respondents. Television, radio and DVD players were the next three most accessible, respectively. Between genders, there was no significant difference in their preferences for most communications media (Figure 12). Landline telephones and computers were the least accessible communications media; only a limited number of respondents owned these devices. There was no significant difference of the ranking of most accessible communications media between village categories, genders and provinces. Only magazines and newspapers were accessed more often by men than women because usually these media were available in the village or sub-district offices, which were attended by men for meetings. 


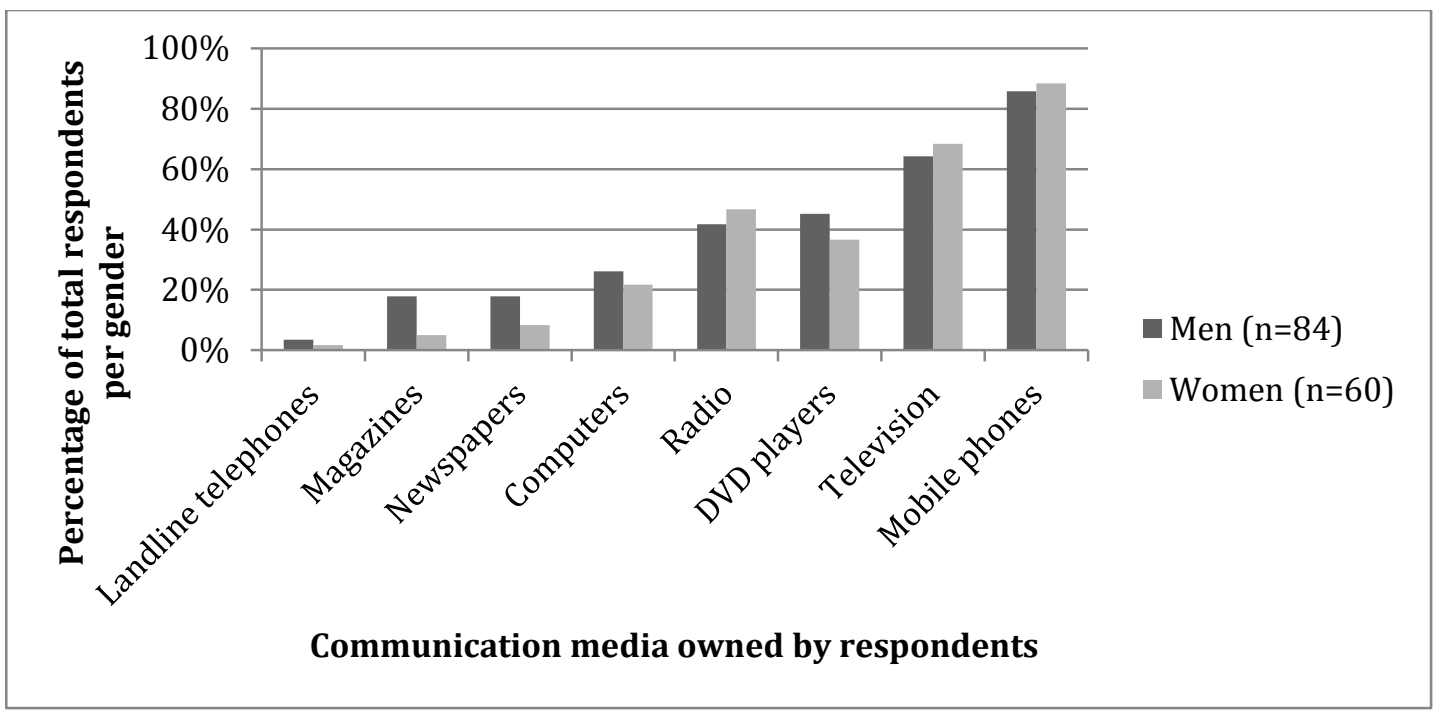

Figure 12. Communications media owned by respondents in South and Southeast Sulawesi provinces

\subsubsection{Television and radio}

Based on discussions with respondents in both provinces, television and radio were the two media that had the highest potential as channels for disseminating information about innovations. Thus, we explored further details of respondents' preferences for television and radio; the responses varied between provinces (Figure 13). Respondents identified Indosiar as their most-watched television station in South Sulawesi and tvOne in Southeast Sulawesi. For radio, Campaga Asri and Pantai Selatan were the preferred local radio stations in South Sulawesi while in Southeast Sulawesi respondents chose Radio Republik Indonesia (RRI), the national station. Generally, respondents watched television or listened to radio more often at night (Figure 14.) 


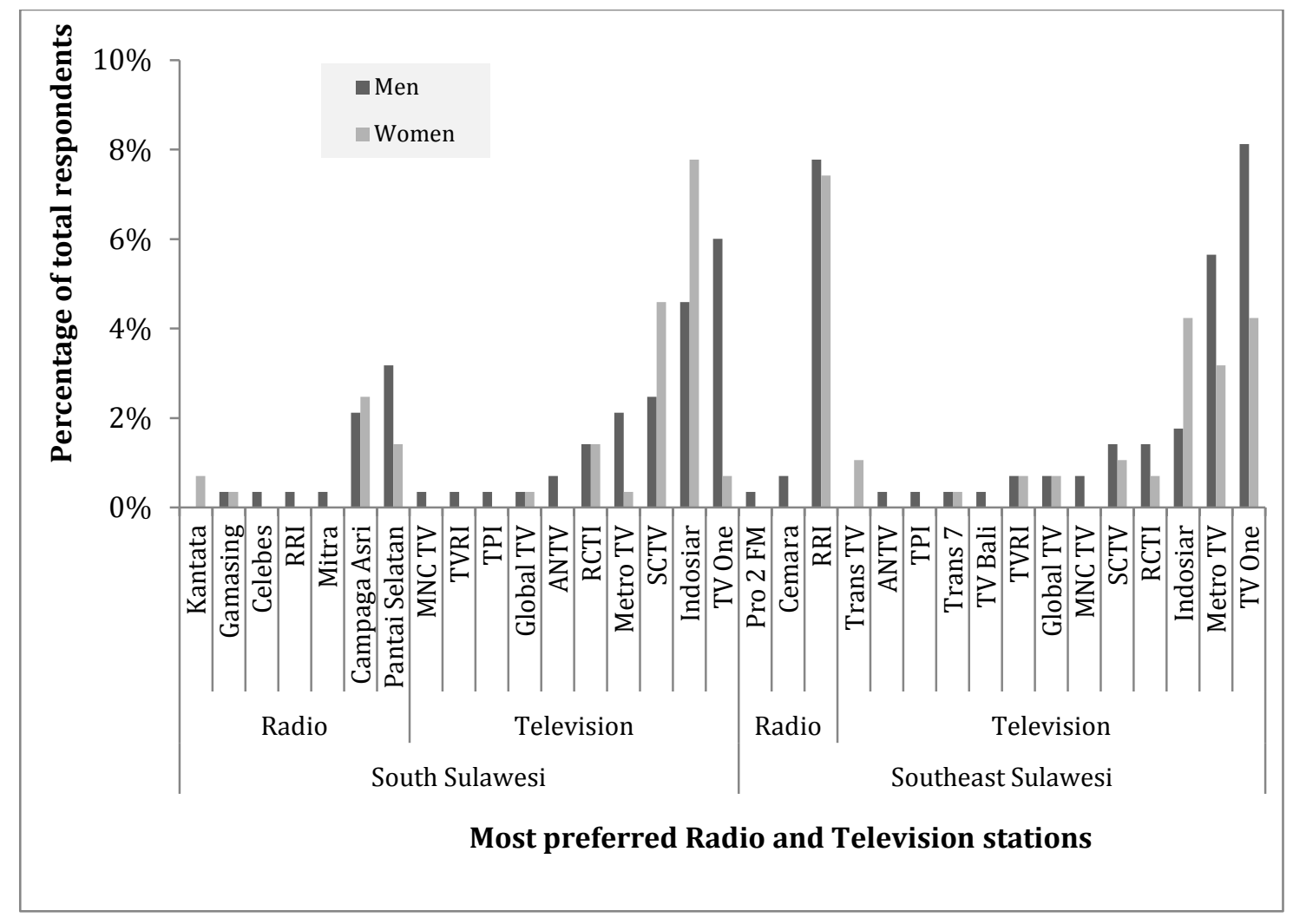

Figure 13. Preferred radio and television stations in South and Southeast Sulawesi provinces

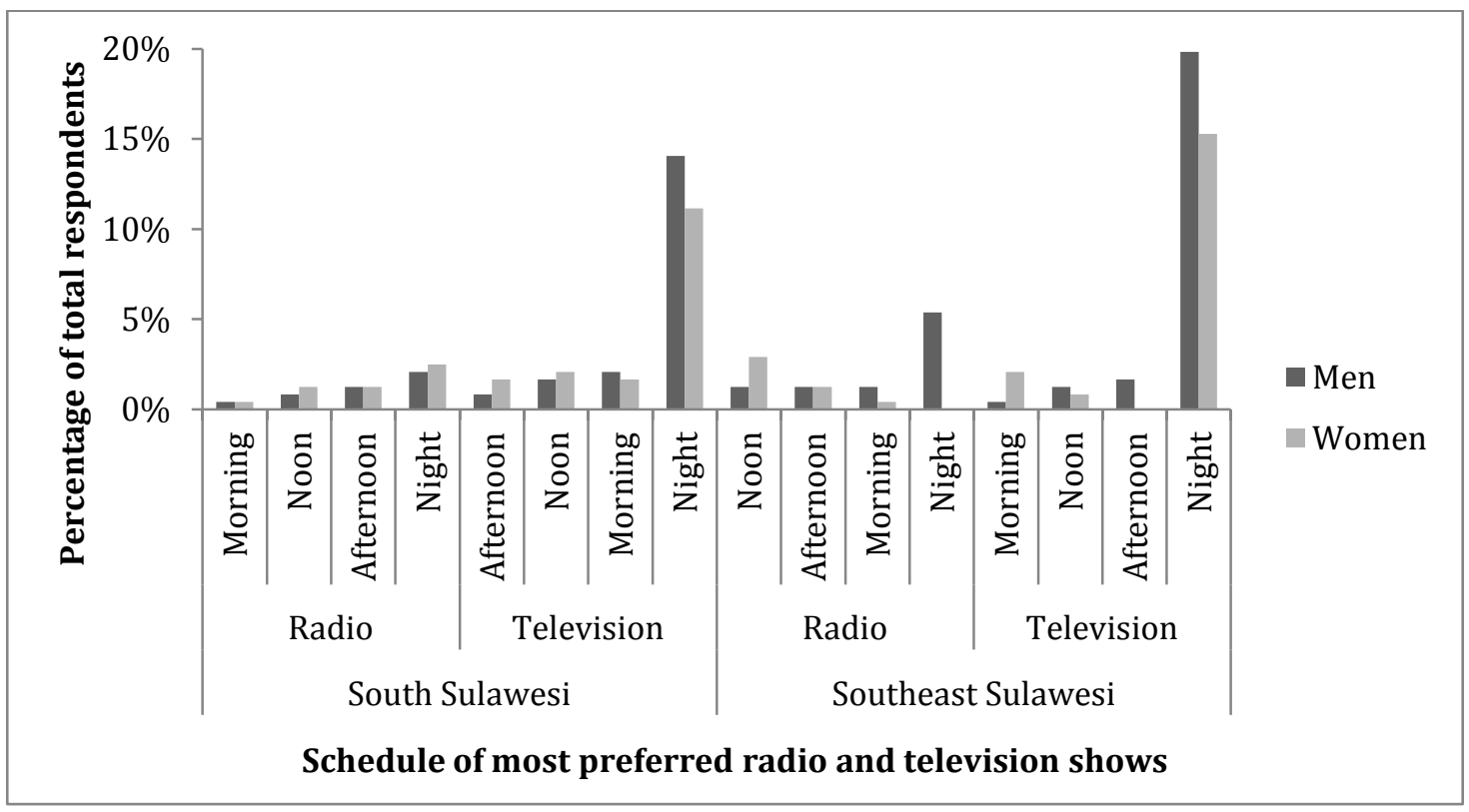

Figure 14. Schedule of preferred radio and television shows in South and Southeast Sulawesi provinces 


\subsection{Personal contacts}

At the study sites, new agroforestry technologies that were adopted by farmers over the past 10 years were those related to 1$)$ cultivating tree species $(28.2 \%) ; 2$ ) producing tree seedlings $(12.4 \%) ; 3)$ vegetative propagation $(10.9 \%)$; 4) effectively applying fertilizer (5.0\%); 5) using innovative agricultural equipment to support better production $(2.6 \%)$.

Those new agroforestry technologies were introduced through various channels. Personal contacts or face-to-face communication was one of the channels used by farmers for obtanining new information. The people who played a role in disseminating innovations via personal contacts varied between areas. In South Sulawesi, the disseminators were opinion leaders (22\%) followed by government officers $(21 \%)$, farmers $(18 \%)$, the private sector (12\%), extension agents (10\%), traders (9\%), farmers' groups (4\%), staff of agroforestry projects $(2 \%)$ and family (2\%). In Southeast Sulawesi, staff of agroforestry projects (37\%) played the major role in the dissemination of agroforestry innovations, followed by farmers (27\%), family (12\%), government officers (12\%), opinion leaders (8\%), and the private sector (4\%). Thus, leading farmers and opinion leaders' roles in disseminating agroforestry innovations was more important in South Sulawesi than in Southeast Sulawesi while staff of agroforestry projects were more important disseminators in Southeast Sulawesi than in South Sulawesi.

In both provinces, farmers and other community members frequently consulted local opinion leaders or successful farmers for solutions to agricultural issues. Common types of information sought by farmers from opinion leaders included agronomy in general (30\%), pests and diseases handling (28\%), availability of agricultural aids (aids for planting material or fertilizers) (9\%), new varieties/species/commodities (9\%), assistance for farmers' groups and agricultural production aids (7\%), vegetative propagation (5\%), market information (4\%), times for planting (4\%), fertilizing and nurseries (2\%), and agricultural extension services (2\%) (Figure 15). To answer the questions, opinion leaders updated their agricultural knowledge by visiting government offices or engaging in self-learning at least once a week. Self-learning included one-on-one discussions with experts or other knowledgeable people, watching specific TV shows, and reading newspapers. 


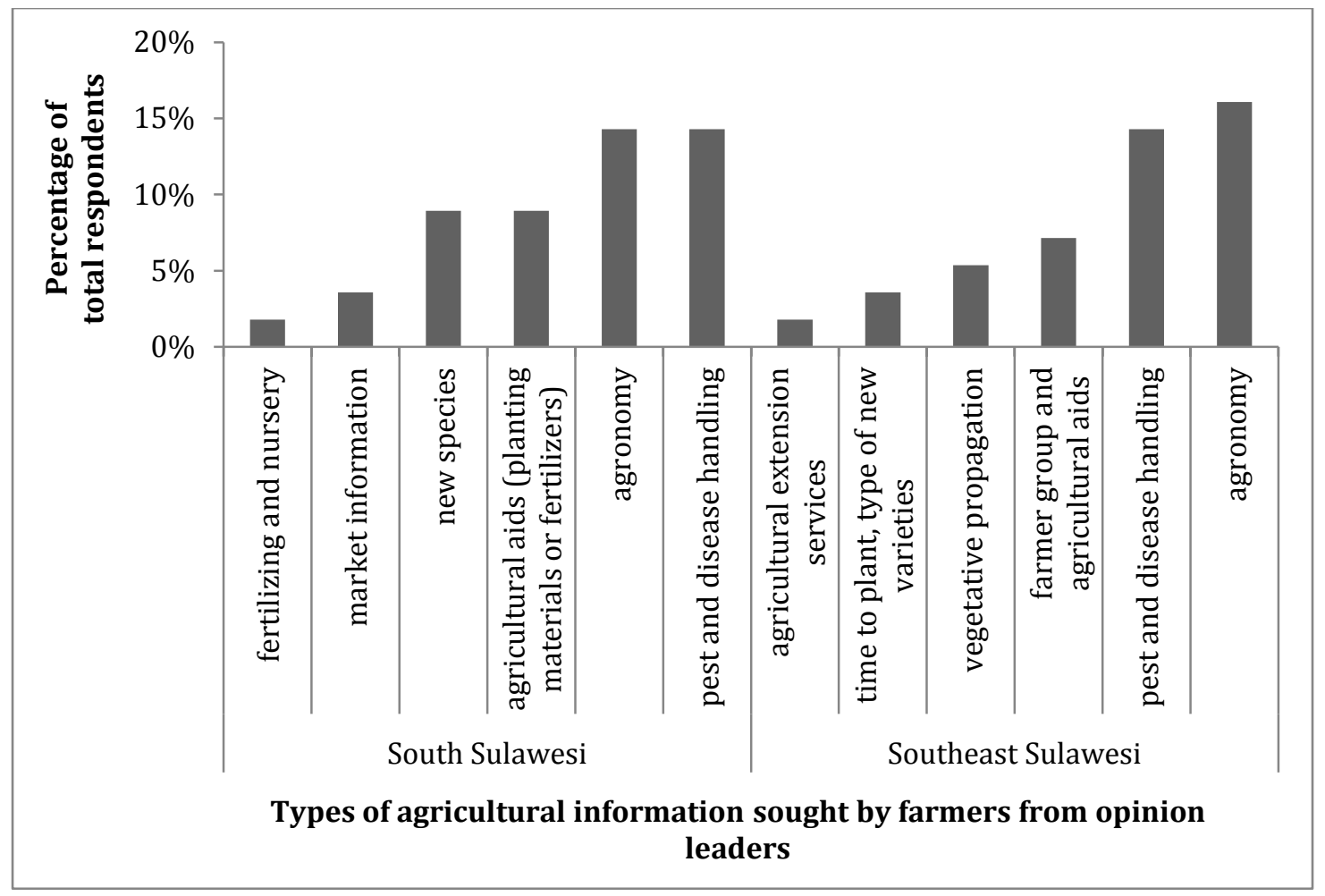

Figure 15. Types of agricultural information sought by farmers from opinion leaders

\subsection{Formal extension services}

\subsubsection{General extension services}

In the past 5 years, $75 \%$ of respondents received extension services on general topics, with men $(46 \%)$ receiving more than women (29\%) (Figure 16). In both provinces, agriculture and health were the two main topics for extension. Respondents felt that by attending extension events they received new knowledge, which was their main motivation to attend. Afterwards, respondents exchanged their knowledge with other people. 


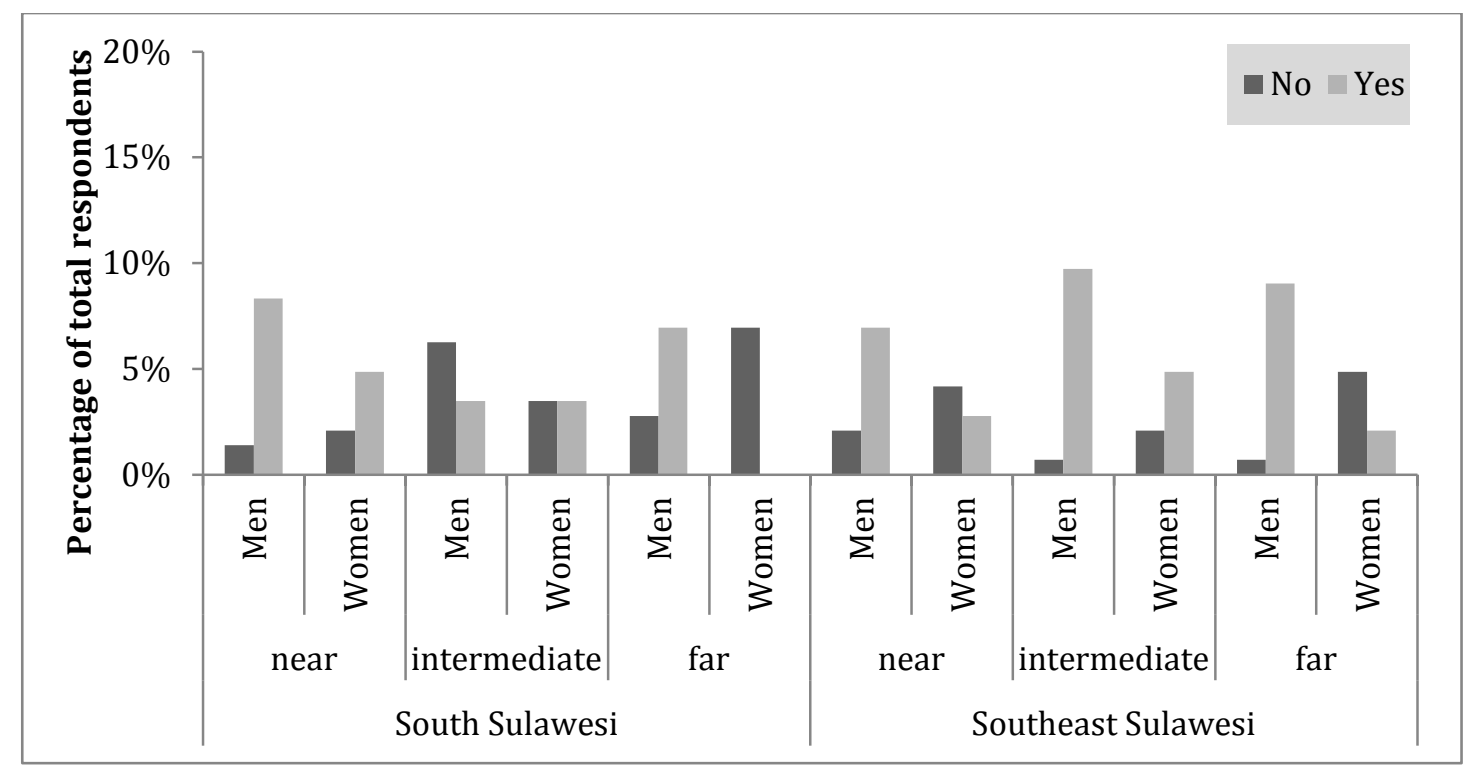

Figure 16. Respondents who received extension services in the past 5 years in South and Southeast Sulawesi

Sixty-three percent (63\%) of total respondents attended agricultural extension events conducted both by government and other extension agents: 27\% in South Sulawesi and 36\% in Southeast Sulawesi. In general, respondents who attended agricultural extension events were $45 \%$ men and $18 \%$ women. Low female attendance was due to the distance of villages from the district capital where events were held. In South Sulawesi, where the villages were located far from the district capital, the attendance of women at agricultural extension events was almost zero.

\subsubsection{Preferences for agricultural extension methods}

The study identified two types of common agricultural extension methods in both provinces: 1) discussion; and 2) practice. We asked respondents to select the most effective and preferred. In South Sulawesi, farmers mostly preferred discussions whereas in Southeast Sulawesi farmers tended to prefer practice (Figure 17). 


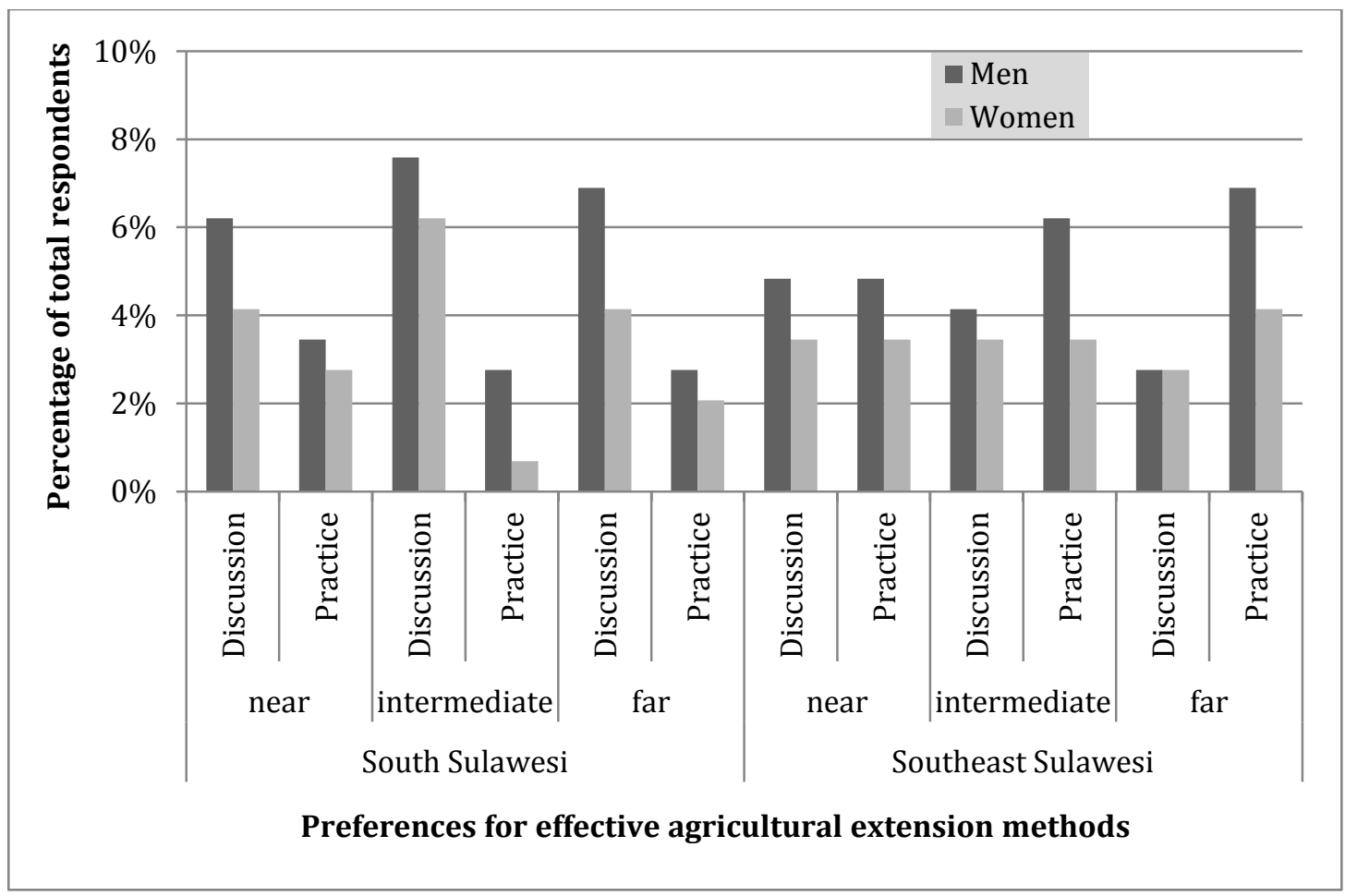

Figure 17. Preferences for effective agricultural extension methods based on respondents' perceptions by gender (men, women) and category of village (near, intermediate, far) in South and Southeast Sulawesi provinces

Preferences were not significant between gender and village classes in each province. Between ethnicities in both South and Southeast Sulawesi there was no significant difference in respondents' preferences (Figure 18). 


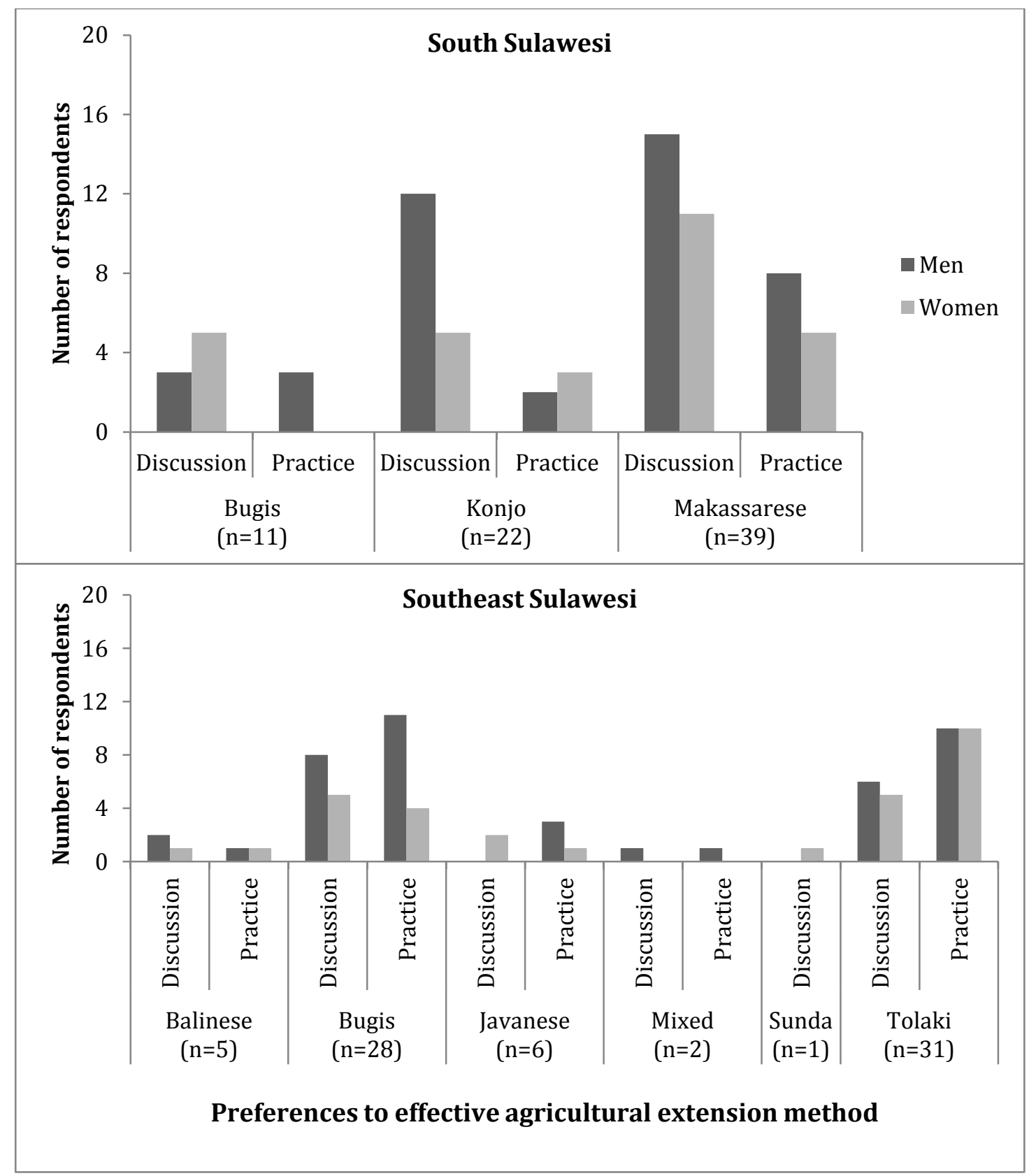

Figure 18. Preferences for effective agricultural extension methods based on respondents' perception by gender and by ethnicities in South and Southeast Sulawesi provinces

Based on respondents' perceptions, effective agricultural extension methods need to be supported by good disseminators or extension agents with the following characteristics: 1) able to provide information that is reliable, trustworthy, new, proven and easy to understand and apply; 2) open for discussion; 3) can meet on a daily basis or regularly; 4) have plenty of knowledge and experience; and 5) able to demonstrate examples.

\subsubsection{Gender in agricultural extension services}

Of the total of 60 female respondents, 37 attended agricultural extension events, with $62 \%$ in Southeast Sulawesi and 38\% in South Sulawesi. There was no clear correlation between distances to the district capital with female participation in agricultural extension services in 
South Sulawesi (Figure 19). In Southeast Sulawesi, distance of the village to the district capital affected women's attendance at extension events: the closer the village to the district capital, the more women participated. Villages located near the district capital have better access to extension events. In villages located far from the district capital, men had more opportunities for attending extension events than women. This was because it usually required driving by motorcycle to reach events in the capital.

The lower level of female participation in agricultural extension events in South Sulawesi was due to: 1) perceptions in the community that agriculture or agroforestry was a male domain; 2) organizers inviting only men to attend events; and 3) women's household responsibilities that limited their availability. Higher participation of women at extension events in Southeast Sulawesi was partially due to organizers requiring participants to be both men and women, that is, the organizers were formally inviting women.

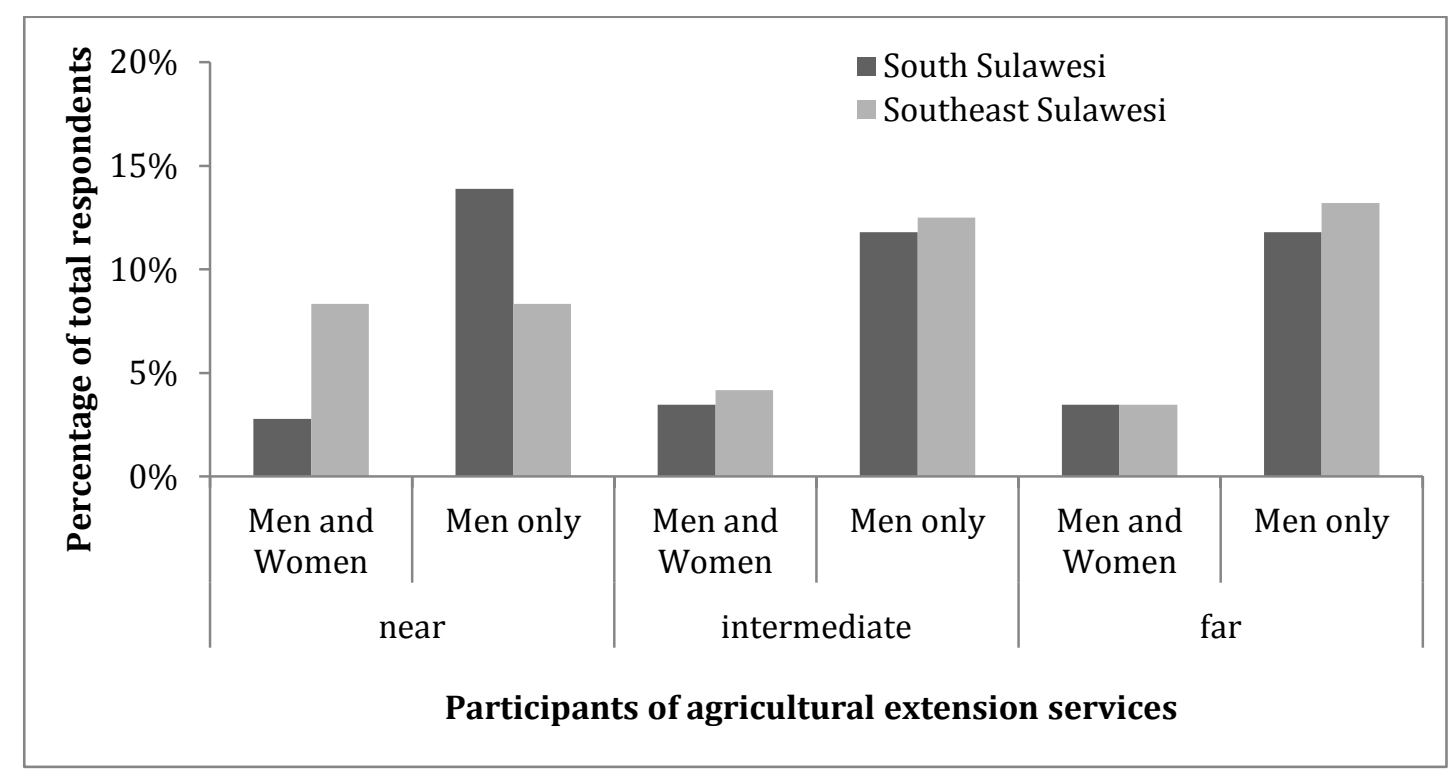

Figure 19. Participation by gender in agricultural extension events in South and Southeast Sulawesi

\subsubsection{Agricultural extension communication media}

Only $44.4 \%$ of the total respondents received extension material during extension activities they attended. Respondents in South Sulawesi received more extension media (23.6\%) than those in Southeast Sulawesi (20.8\%). In both provinces, men (32.6\%) received more extension media than women (11.8\%). This was related to more male participants attending agricultural extension events. Books or booklets were the most common extension materials given to farmers. The next most commonly received materials were leaflets, posters and DVDs, respectively.

Respondents appreciated the distribution of extension media, particularly, because it helped them gain new knowledge, could be re-read (or reviewed) if they forgot the details, and helped the extension process. However, only respondents with formal education longer than 9 years tended to maintain an organized collection of the material they received. 


\subsection{Social events}

Besides receiving new information via mass media, opinion leaders or extension services, new information was also disseminated via community gatherings, such as 'arisan' (informal lottery), 'gotong royong' (mutual aid activities), religious events and community meetings. On a weekly basis, communities met through arisan, gotong royong and religious meetings. Monthly, they met in larger groups through community meetings, such as farmers', youth and women's groups. Occasionally, they also met at weddings or customary occasions where they could exchange information. Weddings were a key opportunity to meet people from other villages.

\section{Conclusions}

The study provided baseline data on how village communities obtain new information, particularly, information on agricultural and agroforestry innovations. In general, distance from the district capital did not significantly affect communities' access to new information. The main factors limiting farmers' access to information was poor infrastructure, which is a common occurrence in Southeast Sulawesi. Poor infrastructure limited extension agents' ability to visit communities, which led to farmers playing a major role as agroforestry innovation disseminators. In locations where access to formal extension services was limited, personal contacts was the preferred information channel for disseminating agroforestry innovations. Between ethnicities, there was no clear difference regarding farmers' preferences for information channels.

From a gender perspective, men tended to have better access to extension services than women. Women's low access to extension services was different for specific reasons in each province. In Southeast Sulawesi, women had less access to extension services mainly because the activities were often conducted far from most villages. In South Sulawesi, the main reason limiting women's access was the cultural perception that considered tree-garden management as a male domain.

For obtaining new information, women preferred to ask family members and, sometimes, opinion leaders while men tended to access more diverse information channels, that is, personal contacts, government extension services, mass media and social gatherings. Women tended to depend on sources of information from sources inside the village whereas men more frequently obtained information from outside the village.

In South Sulawesi, language was a barrier in disseminating agroforestry innovations, particularly, for farmers with elementary school education and below. Farmers who could not speak fluent Indonesian tended to obtain new information from their peers and family. Thus, expert farmers, opinion leaders or extension officers who could speak the local language were more effective disseminators for farmers who only spoke the local language.

There are several implications from this study's findings in disseminating agroforestry innovations developed through the AgFor project in South and Southeast Sulawesi provinces. 
1) Farmer's access to infomation in both provinces needs to be improved by, first, identifying the information needs of each village through focus-group discussions. Needs should be identified before project activities are implemented with farmers. The role of existing information channels (personal contacts, mass media, extension services) for disseminating agroforestry can be enhanced by improving the capacity, and access to information, of important information disseminators in each village. In South Sulawesi, opinion leaders and expert farmers were important for disseminating agroforestry innovation while in Southeast Sulawesi staff of agroforestry projects were the more important agroforestry disseminators.

2) Extension methods used by AgFor to disseminate innovations in both provinces should be a combination of discussion and practice, with a greater emphasis on practice in Southeast Sulawesi and greater emphasis on discussion in South Sulawesi. Farmers' field schools are a type of extension method that can facilitate the application of both discussion and practice for disseminating agroforestry innovations. Besides farmers' field schools, biweekly visits by project staff should be conducted via either formal or informal events, such as during gotong royong or arisan. In areas where language is a barrier, such as in South Sulawesi, involving farmers as extension agents is recommended.

3) Communication media that have the potential to be used by AgFor are printed and radio. Radio and television are potential mass media for spreading information in both provinces, however, radio is more cost effective and feasible owing to the high cost of engaging in television programming. Any kind of print media is important to develop because there are still limited amounts and types of information about agricultural innovations given to farmers. When developing print media for farmers, we advise using more illustrations because reading was less preferred by farmers when learning new technologies. Reading was only prefered by respondents with education levels of high school and above. At AgFor sites, most villagers have education levels limited to elementary school or below.

4) Low attendance by women at agricultural extension events can be countered by formally inviting more women to attend. Holding events in villages will enhance women's opportunity to participate. In both provinces, women preferred audiovisual for learning new things, thus, AgFor should produce more audiovisual products to enhance women's accesss to agroforestry innovations. Equal distribution to women and men needs to be considered when distributing media. 


\section{References}

Janudianto, Khususiyah N, Isnurdiansyah, Suyanto, Roshetko JM. 2012. Agroforestry and Forestry in Sulawesi series: livelihood strategies and land-use system dynamics in Southeast Sulawesi.

Working paper 156. Bogor, Indonesia: World Agroforestry Centre (ICRAF). http://www.worldagroforestry.org/downloads/publications/PDFs/WP12055.PDF

Khususiyah N, Janudianto, Isnurdiansyah, Suyanto, Roshetko JM. 2012. Agroforestry and Forestry in Sulawesi series: livelihood strategies and land-use system dynamics in South Sulawesi. Working paper 155. Bogor, Indonesia: World Agroforestry Centre (ICRAF).

http://www.worldagroforestry.org/WP12054.PDF

Martini E, Tarigan J, Purnomosidhi P, Prahmono A, Surgana M, Setiawan E, Megawati, Mulyoutami E, Meldy BW, Syamsidar, Talui R, Janudianto, Suyanto, Roshetko JM. 2012. Agroforestry and Forestry in Sulawesi series: Agroforestry extension needs at the community level in AgFor project sites in South and Southeast Sulawesi, Indonesia. Working paper 159. Bogor, Indonesia: World Agroforestry Centre (ICRAF) Southeast Asia Regional Program. DOI: 10.5716/WP12058.PDF.

Mulyoutami E, Martini E, Khususiyah N, Isnurdiansyah I, Suyanto S. 2012. Agroforestry and Forestry in Sulawesi series: Gender, livelihoods and land in South and Southeast Sulawesi. Working paper 158. Bogor, Indonesia: World Agroforestry Centre (ICRAF) Southeast Asia Regional Program. DOI: 10.5716/WP12057.PDF. 


\section{WORKING PAPERS WITH DOIS}

\section{5}

1. Agroforestry in the drylands of eastern Africa: a call to action

2. Biodiversity conservation through agroforestry: managing tree species diversity within a network of community-based, nongovernmental, governmental and research organizations in western Kenya.

3. Invasion of prosopis juliflora and local livelihoods: Case study from the Lake Baringo area of Kenya

4. Leadership for change in farmers organizations: Training report: Ridar Hotel, Kampala, 29th March to 2nd April 2005.

5. Domestication des espèces agroforestières au Sahel : situation actuelle et perspectives

6. Relevé des données de biodiversité ligneuse: Manuel du projet biodiversité des parcs agroforestiers au Sahel

7. Improved land management in the Lake Victoria Basin: TransVic Project's draft report.

8. Livelihood capital, strategies and outcomes in the Taita hills of Kenya

9. Les espèces ligneuses et leurs usages: Les préférences des paysans dans le Cercle de Ségou, au Mali

10. La biodiversité des espèces ligneuses: Diversité arborée et unités de gestion du terroir dans le Cercle de Ségou, au Mali

\section{6}

11. Bird diversity and land use on the slopes of Mt. Kilimanjaro and the adjacent plains, Tanzania

12. Water, women and local social organization in the Western Kenya Highlands

13. Highlights of ongoing research of the World Agroforestry Centre in Indonesia

14. Prospects of adoption of tree-based systems in a rural landscape and its likely impacts on carbon stocks and farmers' welfare: The FALLOW Model Application in Muara Sungkai, Lampung, Sumatra, in a 'Clean Development Mechanism' context

15. Equipping integrated natural resource managers for healthy Agroforestry landscapes.

17. Agro-biodiversity and CGIAR tree and forest science: approaches and examples from Sumatra.

18. Improving land management in eastern and southern Africa: A review of policies.

19. Farm and household economic study of Kecamatan Nanggung, Kabupaten Bogor, Indonesia: A socioeconomic base line study of Agroforestry innovations and livelihood enhancement.

20. Lessons from eastern Africa's unsustainable charcoal business.

21. Evolution of RELMA's approaches to land management: Lessons from two decades of research and development in eastern and southern Africa

22. Participatory watershed management: Lessons from RELMA's work with farmers in eastern Africa.

23. Strengthening farmers' organizations: The experience of RELMA and ULAMP.

24. Promoting rainwater harvesting in eastern and southern Africa.

25. The role of livestock in integrated land management.

26. Status of carbon sequestration projects in Africa: Potential benefits and challenges to scaling up.

27. Social and Environmental Trade-Offs in Tree Species Selection: A Methodology for Identifying Niche Incompatibilities in Agroforestry [Appears as AHI Working Paper no. 9]

28. Managing tradeoffs in agroforestry: From conflict to collaboration in natural resource management. [Appears as AHI Working Paper no. 10]

29. Essai d'analyse de la prise en compte des systemes agroforestiers pa les legislations forestieres au Sahel: Cas du Burkina Faso, du Mali, du Niger et du Senegal.

30. Etat de la recherche agroforestière au Rwanda etude bibliographique, période 1987-2003 
31. Science and technological innovations for improving soil fertility and management in Africa: A report for NEPAD's Science and Technology Forum.

32. Compensation and rewards for environmental services.

33. Latin American regional workshop report compensation.

34. Asia regional workshop on compensation ecosystem services.

35. Report of African regional workshop on compensation ecosystem services.

36. Exploring the inter-linkages among and between compensation and rewards for ecosystem services CRES and human well-being

37. Criteria and indicators for environmental service compensation and reward mechanisms: realistic, voluntary, conditional and pro-poor

38. The conditions for effective mechanisms of compensation and rewards for environmental services.

39. Organization and governance for fostering Pro-Poor Compensation for Environmental Services.

40. How important are different types of compensation and reward mechanisms shaping poverty and ecosystem services across Africa, Asia \& Latin America over the Next two decades?

41. Risk mitigation in contract farming: The case of poultry, cotton, woodfuel and cereals in East Africa.

42. The RELMA savings and credit experiences: Sowing the seed of sustainability

43. Yatich J., Policy and institutional context for NRM in Kenya: Challenges and opportunities for Landcare.

44. Nina-Nina Adoung Nasional di So! Field test of rapid land tenure assessment (RATA) in the Batang Toru Watershed, North Sumatera.

45. Is Hutan Tanaman Rakyat a new paradigm in community based tree planting in Indonesia?

46. Socio-Economic aspects of brackish water aquaculture (Tambak) production in Nanggroe Aceh Darrusalam.

47. Farmer livelihoods in the humid forest and moist savannah zones of Cameroon.

48. Domestication, genre et vulnérabilité : Participation des femmes, des Jeunes et des catégories les plus pauvres à la domestication des arbres agroforestiers au Cameroun.

49. Land tenure and management in the districts around Mt Elgon: An assessment presented to the Mt Elgon ecosystem conservation programme.

50. The production and marketing of leaf meal from fodder shrubs in Tanga, Tanzania: A pro-poor enterprise for improving livestock productivity.

51. Buyers Perspective on Environmental Services (ES) and Commoditization as an approach to liberate ES markets in the Philippines.

52. Towards Towards community-driven conservation in southwest China: Reconciling state and local perceptions.

53. Biofuels in China: An Analysis of the Opportunities and Challenges of Jatropha curcas in Southwest China.

54. Jatropha curcas biodiesel production in Kenya: Economics and potential value chain development for smallholder farmers

55. Livelihoods and Forest Resources in Aceh and Nias for a Sustainable Forest Resource Management and Economic Progress

56. Agroforestry on the interface of Orangutan Conservation and Sustainable Livelihoods in Batang Toru, North Sumatra. 
57. Assessing Hydrological Situation of Kapuas Hulu Basin, Kapuas Hulu Regency, West Kalimantan.

58. Assessing the Hydrological Situation of Talau Watershed, Belu Regency, East Nusa Tenggara.

59. Kajian Kondisi Hidrologis DAS Talau, Kabupaten Belu, Nusa Tenggara Timur.

60. Kajian Kondisi Hidrologis DAS Kapuas Hulu, Kabupaten Kapuas Hulu, Kalimantan Barat.

61. Lessons learned from community capacity building activities to support agroforest as sustainable economic alternatives in Batang Toru orang utan habitat conservation program (Martini, Endri et al.)

62. Mainstreaming Climate Change in the Philippines.

63. A Conjoint Analysis of Farmer Preferences for Community Forestry Contracts in the Sumber Jaya Watershed, Indonesia.

64. The highlands: a shared water tower in a changing climate and changing Asia

65. Eco-Certification: Can It Deliver Conservation and Development in the Tropics.

66. Designing ecological and biodiversity sampling strategies. Towards mainstreaming climate change in grassland management.

67. Towards mainstreaming climate change in grassland management policies and practices on the Tibetan Plateau

68. An Assessment of the Potential for Carbon Finance in Rangelands

69 ECA Trade-offs Among Ecosystem Services in the Lake Victoria Basin.

69. The last remnants of mega biodiversity in West Java and Banten: an in-depth exploration of RaTA (Rapid Land Tenure Assessment) in Mount Halimun-Salak National Park Indonesia

70. Le business plan d'une petite entreprise rurale de production et de commercialisation des plants des arbres locaux. Cas de quatre pépinières rurales au Cameroun.

71. Les unités de transformation des produits forestiers non ligneux alimentaires au Cameroun. Diagnostic technique et stratégie de développement Honoré Tabuna et Ingratia Kayitavu.

72. Les exportateurs camerounais de safou (Dacryodes edulis) sur le marché sous régional et international. Profil, fonctionnement et stratégies de développement.

73. Impact of the Southeast Asian Network for Agroforestry Education (SEANAFE) on agroforestry education capacity.

74. Setting landscape conservation targets and promoting them through compatible land use in the Philippines.

75. Review of methods for researching multistrata systems.

76. Study on economical viability of Jatropha curcas L. plantations in Northern Tanzania assessing farmers' prospects via cost-benefit analysis

77. Cooperation in Agroforestry between Ministry of Forestry of Indonesia and International Center for Research in Agroforestry

78. "China's bioenergy future. an analysis through the Lens if Yunnan Province

79. Land tenure and agricultural productivity in Africa: A comparative analysis of the economics literature and recent policy strategies and reforms

80. Boundary organizations, objects and agents: linking knowledge with action in Agroforestry watersheds

81. Reducing emissions from deforestation and forest degradation (REDD) in Indonesia: options and challenges for fair and efficient payment distribution mechanisms 
82. Mainstreaming climate change into agricultural education: challenges and perspectives

83. Challenging conventional mindsets and disconnects in conservation: the emerging role of ecoagriculture in Kenya's landscape mosaics

84. Lesson learned RATA garut dan bengkunat: suatu upaya membedah kebijakan pelepasan kawasan hutan dan redistribusi tanah bekas kawasan hutan

85. The emergence of forest land redistribution in Indonesia

86. Commercial opportunities for fruit in Malawi

87. Status of fruit production processing and marketing in Malawi

88. Fraud in tree science

89. Trees on farm: analysis of global extent and geographical patterns of agroforestry

90. The springs of Nyando: water, social organization and livelihoods in Western Kenya

91. Building capacity toward region-wide curriculum and teaching materials development in agroforestry education in Southeast Asia

92. Overview of biomass energy technology in rural Yunnan (Chinese - English abstract)

93. A pro-growth pathway for reducing net GHG emissions in China

94. Analysis of local livelihoods from past to present in the central Kalimantan Ex-Mega Rice Project area

95. Constraints and options to enhancing production of high quality feeds in dairy production in Kenya, Uganda and Rwanda

2010

96. Agroforestry education in the Philippines: status report from the Southeast Asian Network for Agroforestry Education (SEANAFE)

97. Economic viability of Jatropha curcas L. plantations in Northern Tanzania- assessing farmers' prospects via cost-benefit analysis.

98. Hot spot of emission and confusion: land tenure insecurity, contested policies and competing claims in the central Kalimantan Ex-Mega Rice Project area

99. Agroforestry competences and human resources needs in the Philippines

100. CES/COS/CIS paradigms for compensation and rewards to enhance environmental Services

101. Case study approach to region-wide curriculum and teaching materials development in agroforestry education in Southeast Asia

102. Stewardship agreement to reduce emissions from deforestation and degradation (REDD): Lubuk Beringin's Hutan Desa as the first village forest in Indonesia

103. Landscape dynamics over time and space from ecological perspective

104. Komoditisasi atau koinvestasi jasa lingkungan: skema imbal jasa lingkungan program peduli sungai di DAS Way Besai, Lampung, Indonesia

105. Improving smallholders' rubber quality in Lubuk Beringin, Bungo district, Jambi province, Indonesia: an initial analysis of the financial and social benefits

106. Rapid Carbon Stock Appraisal (RACSA) in Kalahan, Nueva Vizcaya, Philippines

107. Tree domestication by ICRAF and partners in the Peruvian Amazon: lessons learned and future prospects in the domain of the Amazon Initiative eco-regional program

108. Memorias del Taller Nacional: "Iniciativas para Reducir la Deforestación en la region Andino Amazónica", 09 de Abril del 2010. Proyecto REALU Peru

109. Percepciones sobre la Equidad y Eficiencia en la cadena de valor de REDD en Perú -Reporte de Talleres en Ucayali, San Martín y Loreto, 2009. Proyecto REALU-Perú. 
110. Reducción de emisiones de todos los Usos del Suelo. Reporte del Proyecto REALU Perú Fase 1

111. Programa Alternativas a la Tumba-y-Quema (ASB) en el Perú. Informe Resumen y Síntesis de la Fase II. 2da. versión revisada

112. Estudio de las cadenas de abastecimiento de germoplasma forestal en la amazonía Boliviana

113. Biodiesel in the Amazon

114. Estudio de mercado de semillas forestales en la amazonía Colombiana

115. Estudio de las cadenas de abastecimiento de germoplasma forestal en Ecuador http://dx.doi.org10.5716/WP10340.PDF

116. How can systems thinking, social capital and social network analysis help programs achieve impact at scale?

117. Energy policies, forests and local communities in the Ucayali Region, Peruvian Amazon

118. NTFPs as a Source of Livelihood Diversification for Local Communities in the Batang Toru Orangutan Conservation Program

119. Studi Biodiversitas: Apakah agroforestry mampu mengkonservasi keanekaragaman hayati di DAS Konto?

120. Estimasi Karbon Tersimpan di Lahan-lahan Pertanian di DAS Konto, Jawa Timur

121. Implementasi Kaji Cepat Hidrologi (RHA) di Hulu DAS Brantas, Jawa Timur. http://dx.doi.org/10.5716/WP10338.PDF

122. Kaji Cepat Hidrologi di Daerah Aliran Sungai Krueng Peusangan, NAD,Sumatra http://dx.doi.org/10.5716/WP10337.PDF

123. A Study of Rapid Hydrological Appraisal in the Krueng Peusangan Watershed, NAD, Sumatra. http://dx.doi.org/10.5716/WP10339.PDF

2011

124. An Assessment of farm timber value chains in Mt Kenya area, Kenya

125. A Comparative financial analysis of current land use systems and implications for the adoption of improved agroforestry in the East Usambaras, Tanzania

126. Agricultural monitoring and evaluation systems

127. Challenges and opportunities for collaborative landscape governance in the East Usambara Mountains, Tanzania

128. Transforming Knowledge to Enhance Integrated Natural Resource Management Research, Development and Advocacy in the Highlands of Eastern Africa http://dx.doi.org/10.5716/WP11084.PDF

129. Carbon-forestry projects in the Philippines: potential and challenges The Mt Kitanglad Range forestcarbon development http://dx.doi.org10.5716/WP11054.PDF

130. Carbon forestry projects in the Philippines: potential and challenges. The Arakan Forest Corridor forest-carbon project. http://dx.doi.org10.5716/WP11055.PDF

131. Carbon-forestry projects in the Philippines: potential and challenges. The Laguna Lake Development Authority's forest-carbon development project. http://dx.doi.org/10.5716/WP11056.PDF

132. Carbon-forestry projects in the Philippines: potential and challenges. The Quirino forest-carbon development project in Sierra Madre Biodiversity Corridor http://dx.doi.org10.5716/WP11057.PDF

133. Carbon-forestry projects in the Philippines: potential and challenges. The Ikalahan Ancestral Domain forest-carbon development http://dx.doi.org10.5716/WP11058.PDF

134. The Importance of Local Traditional Institutions in the Management of Natural Resources in the Highlands of Eastern Africa. http://dx.doi.org/10.5716/WP11085.PDF 
135. Socio-economic assessment of irrigation pilot projects in Rwanda. http://dx.doi.org/10.5716/WP11086.PDF

136. Performance of three rambutan varieties (Nephelium lappaceum L.) on various nursery media. http://dx.doi.org/10.5716/WP11232.PDF

137. Climate change adaptation and social protection in agroforestry systems: enhancing adaptive capacity and minimizing risk of drought in Zambia and Honduras http://dx.doi.org/10.5716/WP11269.PDF

138. Does value chain development contribute to rural poverty reduction? Evidence of asset building by smallholder coffee producers in Nicaragua http://dx.doi.org/10.5716/WP11271.PDF

139. Potential for biofuel feedstock in Kenya. http://dx.doi.org/10.5716/WP11272.PDF

140. Impact of fertilizer trees on maize production and food security in six districts of Malawi. http://dx.doi.org/10.5716/WP11281.PDF

\section{2}

141. Fortalecimiento de capacidades para la gestión del Santuario Nacional Pampa Hermosa:

Construyendo las bases para un manejo adaptativo para el desarrollo local. Memorias del Proyecto. http://dx.doi.org/10.5716/WP12005.PDF

142. Understanding rural institutional strengthening: A cross-level policy and institutional framework for sustainable development in Kenya http://dx.doi.org/10.5716/WP12012.PDF

143. Climate change vulnerability of agroforestry http://dx.doi.org/10.5716/WP16722.PDF

144. Rapid assesment of the inner Niger delta of Mali http://dx.doi.org/10.5716/WP12021.PDF

145. Designing an incentive program to reduce on-farm deforestationin the East Usambara Mountains, Tanzania http://dx.doi.org/10.5716/WP12048.PDF

146. Extent of adoption of conservation agriculture and agroforestry in Africa: the case of Tanzania, Kenya, Ghana, and Zambia http://dx.doi.org/10.5716/WP12049.PDF

147. Policy incentives for scaling up conservation agriculture with trees in Africa: the case of Tanzania, Kenya, Ghana and Zambia http://dx.doi.org/10.5716/WP12050.PDF

148. Commoditized or co-invested environmental services? Rewards for environmental services scheme: River Care program Way Besai watershed, Lampung, Indonesia. http://dx.doi.org/10.5716/WP12051.PDF

149. Assessment of the headwaters of the Blue Nile in Ethiopia. http://dx.doi.org/10.5716/WP12160.PDF

150. Assessment of the uThukela Watershed, Kwazaulu. http://dx.doi.org/10.5716/WP12161.PDF

151. Assessment of the Oum Zessar Watershed of Tunisia. http://dx.doi.org/10.5716/WP12162.PDF

152. Assessment of the Ruwenzori Mountains in Uganda. http://dx.doi.org/10.5716/WP12163.PDF

153. History of agroforestry research and development in Viet Nam. Analysis of research opportunities and gaps. http://dx.doi.org/10.5716/WP12052.PDF

154. REDD+ in Indonesia: a Historical Perspective. http://dx.doi.org/10.5716/WP12053.PDF

155. Agroforestry and Forestry in Sulawesi series: Livelihood strategies and land use system dynamics in South Sulawesi http://dx.doi.org/10.5716/WP12054.PDF

156. Agroforestry and Forestry in Sulawesi series: Livelihood strategies and land use system dynamics in Southeast Sulawesi. http://dx.doi.org/10.5716/WP12055.PDF

157. Agroforestry and Forestry in Sulawesi series: Profitability and land-use systems in South and Southeast Sulawesi. http://dx.doi.org/10.5716/WP12056.PDF

158. Agroforestry and Forestry in Sulawesi series: Gender, livelihoods and land in South and Southeast Sulawesi http://dx.doi.org/10.5716/WP12057.PDF 
159. Agroforestry and Forestry in Sulawesi series: Agroforestry extension needs at the community level in AgFor project sites in South and Southeast Sulawesi, Indonesia. http://dx.doi.org/10.5716/WP12058.PDF

160. Agroforestry and Forestry in Sulawesi series: Rapid market appraisal of agricultural, plantation and forestry commodities in South and Southeast Sulawesi. http://dx.doi.org/10.5716/WP12059.PDF

\section{3}

161. Diagnosis of farming systems in the Agroforestry for Livelihoods of Smallholder farmers in Northwestern Viet Nam project http://dx.doi.org/10.5716/WP13033.PDF

162. Ecosystem vulnerability to climate change: a literature review. http://dx.doi.org/10.5716/WP13034.PDF

163. Local capacity for implementing payments for environmental services schemes: lessons from the RUPES project in northeastern Viet Nam http://dx.doi.org/10.5716/WP13046.PDF

164. Seri Agroforestri dan Kehutanan di Sulawesi: Agroforestry dan Kehutanan di Sulawesi: Strategi mata pencaharian dan dinamika sistem penggunaan lahan di Sulawesi Selatan http://dx.doi.org/10.5716/WP13040.PDF

165. Seri Agroforestri dan Kehutanan di Sulawesi: Mata pencaharian dan dinamika sistem penggunaan lahan di Sulawesi Tenggara http://dx.doi.org/10.5716/WP13041.PDF

166. Seri Agroforestri dan Kehutanan di Sulawesi: Profitabilitas sistem penggunaan lahan di Sulawesi Selatan dan Sulawesi Tenggara http://dx.doi.org/10.5716/WP13042.PDF

167. Seri Agroforestri dan Kehutanan di Sulawesi: Gender, mata pencarian dan lahan di Sulawesi Selatan dan Sulawesi Tenggara http://dx.doi.org/10.5716/WP13043.PDF

168. Seri Agroforestri dan Kehutanan di Sulawesi: Kebutuhan penyuluhan agroforestri pada tingkat masyarakat di lokasi proyek AgFor di Sulawesi Selatan dan Tenggara, Indonesia. http://dx.doi.org/10.5716/WP13044.PDF

169. Seri Agroforestri dan Kehutanan di Sulawesi: Laporan hasil penilaian cepat untuk komoditas pertanian, perkebunan dan kehutanan di Sulawesi Selatan dan Tenggara http://dx.doi.org/10.5716/WP13045.PDF

170. Agroforestry, food and nutritional security http://dx.doi.org/10.5716/WP13054.PDF

171. Stakeholder Preferences over Rewards for Ecosystem Services: Implications for a REDD+ Benefit Distribution System in Viet Nam http://dx.doi.org/10.5716/WP13057.PDF

172. Payments for ecosystem services schemes: project-level insights on benefits for ecosystems and the rural poor http://dx.doi.org/10.5716/WP13001.PDF

173. Good practices for smallholder teak plantations: keys to success http://dx.doi.org/10.5716/WP13246.PDF

174. Market analysis of selected agroforestry products in the Vision for Change Project intervention Zone, Côte d'Ivoire http://dx.doi.org/10.5716/WP13249.PDF

175. Rattan futures in Katingan: why do smallholders abandon or keep their gardens in Indonesia's 'rattan district'? http://dx.doi.org/10.5716/WP13251.PDF

176. Management along a gradient: the case of Southeast Sulawesi's cacao production landscapes http://dx.doi.org/10.5716/WP13265.PDF

177. Are trees buffering ecosystems and livelihoods in agricultural landscapes of the Lower Mekong Basin? Consequences for climate-change adaptation. http://dx.doi.org/10.5716/WP14047.PDF 
178. Agroforestry, livestock, fodder production and climate change adaptation and mitigation in East Africa: issues and options. http://dx.doi.org/10.5716/WP14050.PDF

179. Trees on farms: an update and reanalysis of agroforestry's global extent and socio-ecological characteristics. http://dx.doi.org/10.5716/WP14064.PDF

180. Beyond reforestation: an assessment of Vietnam's REDD+ readiness. http://dx.doi.org/10.5716/WP14097.PDF

181. Farmer-to-farmer extension in Kenya: the perspectives of organizations using the approach. http://dx.doi.org/10.5716/WP14380.PDF

182. Farmer-to-farmer extension in Cameroon: a survey of extension organizations. http://dx.doi.org/10.5716/WP14383.PDF

183. Farmer-to-farmer extension approach in Malawi: a survey of organizations: a survey of organizations http://dx.doi.org/10.5716/WP14391.PDF

184. Seri Agroforestri dan Kehutanan di Sulawesi: Kuantifikasi jasa lingkungan air dan karbon pola agroforestri pada hutan rakyat di wilayah sungai Jeneberang

185. Options for Climate-Smart Agriculture at Kaptumo Site in Kenyahttp://dx.doi.org/10.5716/WP14394.PDF

\section{5}

186. Agroforestry for Landscape Restoration and Livelihood Development in Central Asia http://dx.doi.org/10.5716/WP14143.PDF

187. "Projected Climate Change and Impact on Bioclimatic Conditions in the Central and South-Central Asia Region" http://dx.doi.org/10.5716/WP14144.PDF

188. Land Cover Changes, Forest Loss and Degradation in Kutai Barat, Indonesia. http://dx.doi.org/10.5716/WP14145.PDF

189. The Farmer-to-Farmer Extension Approach in Malawi: A Survey of Lead Farmers. http://dx.doi.org/10.5716/WP14152.PDF

190. Evaluating indicators of land degradation and targeting agroforestry interventions in smallholder farming systems in Ethiopia. http://dx.doi.org/10.5716/WP14252.PDF

191. Land health surveillance for identifying land constraints and targeting land management options in smallholder farming systems in Western Cameroon

192. Land health surveillance in four agroecologies in Malawi

193. Cocoa Land Health Surveillance: an evidence-based approach to sustainable management of cocoa landscapes in the Nawa region, South-West Côte d'Ivoire http://dx.doi.org/10.5716/WP14255.PDF

194. Situational analysis report: Xishuangbanna autonomous Dai Prefecture, Yunnan Province, China. http://dx.doi.org/10.5716/WP14255.PDF

195. Farmer-to-farmer extension: a survey of lead farmers in Cameroon. http://dx.doi.org/10.5716/WP15009.PDF

196. From transition fuel to viable energy source Improving sustainability in the sub-Saharan charcoal sector http://dx.doi.org/10.5716/WP15011.PDF

197. Mobilizing Hybrid Knowledge for More Effective Water Governance in the Asian Highlands http://dx.doi.org/10.5716/WP15012.PDF

198. Water Governance in the Asian Highlands http://dx.doi.org/10.5716/WP15013.PDF

199. Assessing the Effectiveness of the Volunteer Farmer Trainer Approach in Dissemination of Livestock Feed Technologies in Kenya vis-à-vis other Information Sources http://dx.doi.org/10.5716/WP15022.PDF

200. The rooted pedon in a dynamic multifunctional landscape: Soil science at the World Agroforestry Centre http://dx.doi.org/10.5716/WP15023.PDF 
201. Characterising agro-ecological zones with local knowledge. Case study: Huong Khe district, Ha Tinh, Viet Nam http://dx.doi.org/10.5716/WP15050.PDF

202. Looking back to look ahead: Insight into the effectiveness and efficiency of selected advisory approaches in the dissemination of agricultural technologies indicative of Conservation Agriculture with Trees in Machakos County, Kenya. http://dx.doi.org/10.5716/WP15065.PDF

203. Pro-poor Biocarbon Projects in Eastern Africa Economic and Institutional Lessons. http://dx.doi.org/10.5716/WP15022.PDF

204. Projected climate change impacts on climatic suitability and geographical distribution of banana and coffee plantations in Nepal. http://dx.doi.org/10.5716/WP15294.PDF

205. Agroforestry and Forestry in Sulawesi series: Smallholders' coffee production and marketing in Indonesia. A case study of two villages in South Sulawesi Province. http://dx.doi.org/10.5716/WP15690.PDF

206. Mobile phone ownership and use of short message service by farmer trainers: a case study of Olkalou and Kaptumo in Kenya http://dx.doi.org/10.5716/WP15691.PDF

207. Associating multivariate climatic descriptors with cereal yields: a case study of Southern Burkina Faso http://dx.doi.org/10.5716/WP15273.PDF

208. Preferences and adoption of livestock feed practices among farmers in dairy management groups in Kenya http://dx.doi.org/10.5716/WP15675.PDF

209. Scaling up climate-smart agriculture: lessons learned from South Asia and pathways for success http://dx.doi.org/10.5716/WP15720.PDF

210. Agroforestry and Forestry in Sulawesi series: Local perceptions of forest ecosystem services and collaborative formulation of reward mechanisms in South and Southeast Sulawesi http://dx.doi.org/10.5716/WP15721.PDF

211. Potential and challenges in implementing the co-investment of ecosystem services scheme in Buol District, Indonesia. http://dx.doi.org/10.5716/WP15722.PDF

212. Tree diversity and its utilization by the local community in Buol District, Indonesia http://dx.doi.org/10.5716/WP15723.PDF

213 Vulnerability of smallholder farmers and their preferences on farming practices in Buol District, Indonesia http://dx.doi.org/10.5716/WP15724.PDF

214. Dynamics of Land Use/Cover Change and Carbon Emission in Buol District, Indonesia http://dx.doi.org/10.5716/WP15725.PDF

215. Gender perspective in smallholder farming practices in Lantapan, Phillippines. http://dx.doi.org/10.5716/WP15726.PDF

216. Vulnerability of smallholder farmers in Lantapan, Bukidnon. http://dx.doi.org/10.5716/WP15727.PDF

217. Vulnerability and adaptive capacity of smallholder farmers in Ho Ho Sub-watershed, Ha Tinh Province, Vietnam http://dx.doi.org/10.5716/WP15728.PDF

218. Local Knowledge on the role of trees to enhance livelihoods and ecosystem services in northern central Vietnam http://dx.doi.org/10.5716/WP15729.PDF

219. Land-use/cover change in Ho Ho Sub-watershed, Ha Tinh Province, Vietnam. http://dx.doi.org/10.5716/WP15730.PDF

2016

220. Agroforestry and Forestry in Sulawesi series: Evaluation of the Agroforestry Farmer Field Schools on agroforestry management in South and Southeast Sulawesi, Indonesia.

http://dx.doi.org/10.5716/WP16002.PDF

221 Farmer-to-farmer extension of livestock feed technologies in Rwanda: A survey of volunteer farmer trainers and organizations. http://dx.doi.org/10.5716/WP16005.PDF 
222 Projected Climate Change Impact on Hydrology, Bioclimatic Conditions, and Terrestrial Ecosystems in the Asian Highlands http://dx.doi.org/10.5716/WP16006.PDF

223 Adoption of Agroforestry and its impact on household food security among farmers in Malawi http://dx.doi.org/10.5716/WP16013.PDF

224 Agroforestry and Forestry in Sulawesi series: Information channels for disseminating innovative agroforestry practices to villages in Southern Sulawesi, Indonesia

http://dx.doi.org/10.5716/WP16034.PDF 

The World Agroforestry Centre is an autonomous, non-profit research organization whose vision is a rural transformation in the developing world as smallholder households increase their use of trees in agricultural landscapes to improve food security, nutrition, income, health, shelter, social cohesion, energy resources and environmental sustainability. The Centre generates science-based knowledge about the diverse roles that trees play in agricultural landscapes, and uses its research to advance policies and practices, and their implementation that benefit the poor and the environment. It aims to ensure that all this is achieved by enhancing the quality of its science work, increasing operational efficiency, building and maintaining strong partnerships, accelerating the use and impact of its research, and promoting greater cohesion, interdependence and alignment within the organization.

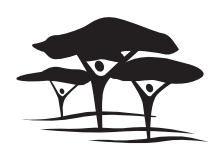

United Nations Avenue, Gigiri • PO Box 30677 • Nairobi, $00100 \cdot$ Kenya Telephone: +254 207224000 or via USA +1 6508336645 Fax: +254207224001 or via USA +16508336646 Email: worldagroforestry@cgiar.org•www.worldagroforestry.org

Southeast Asia Regional Program • Sindang Barang • Bogor 16680 PO Box $161 \cdot$ Bogor $16001 \cdot$ Indonesia

Telephone: +62 $2518625415 \cdot$ Fax: +62 2518625416 